\title{
A REESTRUTURAÇÃO DAS TELECOMUNICAÇÕES E OS SINDICATOS*
}

\section{Sônia M. Guimarães Larangeira}

\section{Introdução}

Fato conhecido, o sindicalismo perdeu mundialmente a influência que deteve em grande parte do século XX, de tal modo que alguns analistas preconizam o fim dessa instituição tão identificada com o mundo industrial. Outros afirmam que o ci-

* Este artigo foi elaborado durante minha estada como pesquisadora visitante na Sloan School of Management, MIT, Cambridge, Ma., de setembro de 2001 a agosto de 2002, o que se tornou possível graças ao financiamento concedido pela Capes. A pesquisa contou também com financiamento da Fapergs. Agradeço ao prof. Paul Osterman, por seus valiosos comentários à versão em inglês, mais extensa, deste trabalho. Agradeço também aos bolsistas IC, Clarissa Gonçalves e Luís Fernando Correa, pelo auxílio na elaboração de gráficos e tabelas.

Artigo recebido em outubro/2002.

Aprovado em maio/2003. clo vital do sindicalismo está intimamente relacionado ao do capitalismo e que, enquanto este existir, aquele permanecerá (Santos, s/d.).

Ao discutir o futuro do sindicalismo, o artigo examina a situação atual a partir da análise do setor de telecomunicações, tentando responder à questão: estão os sindicatos em crise ou construindo novas estratégias? Aborda o caso brasileiro sob a perspectiva do que ocorreu nos Estados Unidos, tendo em vista as mudanças vividas pelo setor em decorrência dos processos de reestruturação, desregulamentação e privatização. As experiências do Reino Unido e da Alemanha são brevemente referidas.

O interesse em tentar "comparar" o caso brasileiro com o dos Estados Unidos está em avaliar as implicações do processo de desregulamentação sobre os sindicatos, considerando que, apesar das diferenças evidentes, ${ }^{1}$ há semelhanças entre os dois casos no que se refere ao modelo de reestru- 
turação adotado, que baseia a competitividade no rebaixamento do custo de mão-de-obra. Nesse aspecto, ambos diferenciam-se do modelo alemão.

Considerando-se que o modelo institucional e de regulação condiciona os padrões de competição e as condições de trabalho e relações sindicais, pode-se supor que, apesar das diferenças existentes quanto à natureza do setor nos dois casos, as conseqüências para os sindicatos de telecomunicações após a desregulamentação e a privatização tendem a se aproximar. Resta saber em que medida há convergência nas reações por parte dos sindicatos em ambos os países.

Os dados relativos ao Brasil foram extraídos dos acordos coletivos firmados pelos sindicatos de empregados de telecomunicações do Rio de Janeiro, de Minas Gerais e do Rio Grande do Sul. Em relação aos Estados Unidos, os dados foram coletados principalmente em entrevistas com lideranças do sindicato norte-americano Communications Workers of America (CWA), realizadas em Washington, DC, em março de 2002. Em relação aos outros países, os dados foram obtidos por meio de fontes secundárias.

\section{O setor de telecomunicações}

Apesar de algumas dificuldades recentes por que passa, o setor de telecomunicações é considerado vital para o desenvolvimento econômico e social da atualidade. Segundo alguns analistas, estaríamos na transição de uma sociedade industrial, cujo símbolo foi a indústria automobilística, para uma sociedade informacional, cujo símbolo seria as telecomunicações. A queda recente dos índices de crescimento do setor, em nível mundial, deve-se, sobretudo, a vultosos investimentos para aquisição, construção e/ou expansão da infra-estrutura e à acirrada competição que resultou no rebaixamento dos preços de serviços. Todavia, esse é um período de ajustamento, e a tendência é de que o setor volte a se expandir.

As mudanças tecnológicas aceleraram-se nos últimos vinte anos. Exemplo disso foi a digitalização do sistema, que tornou os serviços mais versáteis e baratos, favorecendo sua rápida difusão no mundo. Os processos de liberalização e privatização devem ser analisados no contexto dessas mudanças. Há empresas prontas a oferecer novos serviços a um mercado constituído, principalmente, de clientes corporativos, também desejosos de utilizá-los de forma mais eficiente. ${ }^{2}$

A reestruturação representou uma profunda mudança na identidade e nas características do setor. As telecomunicações estruturavam-se em forma de monopólios (em muitos casos, estatais), operavam em mercado nacionais protegidos, como o serviço de utilidade pública e as atividades comerciais restritas, fornecendo serviços de transmissão de voz. A globalização dos serviços requeriu a reestruturação do setor com base na liberalização dos mercados e na privatização. As telecomunicações tornaram-se fornecedoras de uma mercadoria - a comunicação - altamente lucrativa; transformam-se em indústria da informação e de fornecedoras de telefonia fixa em fornecedoras de telefonia celular, de suporte para o tráfego de voz para o tráfego de dados.

No início de 2002, mais da metade dos países no mundo haviam privatizado seus antigos sistemas de telecomunicações estatais e 85\% da renda do mercado mundial era gerada por antigas concessionárias, agora, privatizadas. ${ }^{3}$

A natureza do setor, altamente competitiva e que requer grandes investimentos, contribuiu para sua globalização. As novas tecnologias - celular roaming, sistemas de satélites globais, cartões telefônicos internacionais permitiram a utilização dos serviços fora de sua área de origem. Os celulares de terceira geração foram concebidos para operar em âmbito global. Para obter bons resultados na exploração desses serviços, inserção em novos mercados e ganhos de escala e escopo num mercado bastante competitivo, as empresas realizam fusões, parcerias e aquisições.

Normalmente, consideram-se as telecomunicações um veículo de transmissão de voz. Todavia, o setor, hoje, é muito mais amplo, incluindo: a) serviços de internet; b) rede e tráfego de dados; c) comunicação móvel de terceira geração para a transmissão de base de dados; e d) transmissão de voz por meio de rede de dados. 
Figura 1

USA, 1990: Telecomunicações, US\$ 150 bilhões

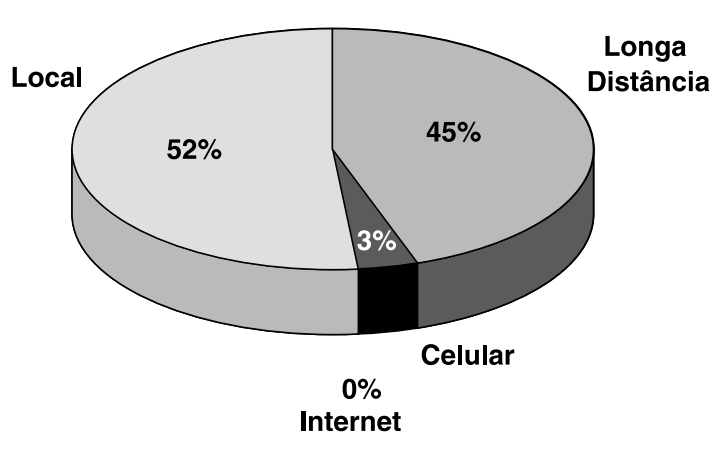

Fonte: CWA (US Outlook, 1999).

Conforme mostram as Figuras 1 e 2, houve uma mudança de perfil do setor nos anos de 1990. Embora referindo-se à realidade norte-americana, os dados expressam uma tendência mundial: a transmissão de voz, que constituía 97\% das atividades do setor em 1990, reduziu-se para $70 \%$, em 1999; a telefonia sem fio cresceu de 3\% para $17 \%$, a internet e a transmissão de dados, não existentes no início do período, alcançaram 13\%, ao final. ${ }^{4}$

O tráfego de dados tem crescido tão rapidamente que alguns analistas afirmam que o conceito de transmissão de dados através de rede fixa de telefone deverá ser substituído pelo conceito de transmissão de vOZ através de rede de Internet. Estima-se que nos anos próximos a transmissão de voz se tornará um nicho de mercado, e a transmissão de dados dominará, inclusive, a rede celular, constituindo-se em cerca de $70 \%$ do tráfego na rede sem fio. ${ }^{5}$

Novos serviços como, por exemplo, a transmissão de gráficos, fotos e utilização de jogos via Internet de alta velocidade em telefones celulares já estão sendo lançados. As fronteiras entre os diferentes ramos da indústria da informação - telefonia fixa, telefonia celular, TV a cabo, computador, serviços de informação, publicação e entretenimento - tendem a desaparecer. ${ }^{6}$

As tendências das telecomunicações podem ser avaliadas observando-se o crescimento da re-
Figura 2

USA, 1999: Telecomunicações, US\$ 310 bilhões

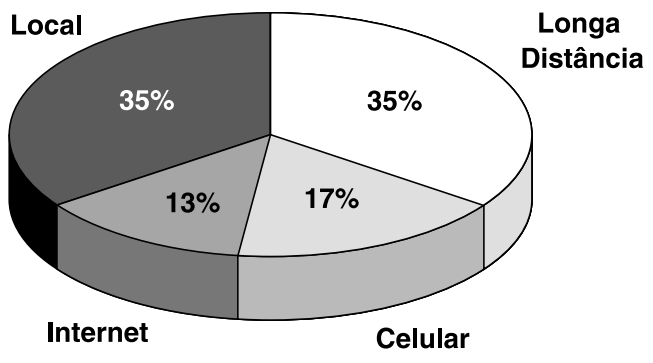

Fonte: CWA (US Outlook, 1999).

ceita em cada um dos segmentos do setor, nos Estados Unidos, conforme mostra a Tabela 1.

Tabela 1

Crescimento da Receita por Segmento (USA)

(Terceiro quadrimestre 2001-2000) (\%)

\begin{tabular}{lr}
\hline Voz/Longa Distância & -20 \\
Transmissão de dados & +19 \\
Celular & +15 \\
Banda Larga & +13 \\
Voz/Local & +4 \\
\hline
\end{tabular}

Fonte: CWA (Relatórios Anuais das Operadoras).

No terceiro semestre de 2001, comparandose com 2000, a receita proveniente de telefonia de longa distância caiu sensivelmente, enquanto o serviço de transmissão de dados, a telefonia celular e a banda larga tiveram crescimento importante; a telefonia local cresceu apenas 4\%. Em relação à telefonia celular, o auge desse crescimento foi no ano de 2000, quando 23,4 milhões de pessoas inscreveram-se como usuários; desde então, os números de inscrição vem caindo, embora sejam ainda expressivos (20,6 milhões, em 2001) (Wall Street Journal, 17.4.2002).? Na maioria dos países desenvolvidos, o mercado para celulares está atingindo a saturação, porém, a estimativa é de que com a difusão da internet, as receitas vol- 
tarão a crescer, já que os usuários poderão adquirir uma série de outros serviços.

O passo seguinte seria focar a telefonia celular em serviços de valor agregado por segmento de mercado, diferenciando usuários corporativos (serviços de dados) dos demais, em especial, o mercado dirigido ao público jovem (serviços multimedia). A segmentação permitiria a redução de preços para atrair novos consumidores sem que essa redução abrangesse os consumidores em geral, como ocorre hoje (Michael Kende, US Wireless: divide and conquer, www.ctia.com). A penetração de celulares nos Estados Unidos (menos de 50\%), em 2001, por exemplo, estava bem abaixo da de muitos países europeus e asiáticos, como, por exemplo, Taiwan, 97\%; Hong Kong; e Itália, 84\% (Grã Bretanha, Development Sector, www.itu.com).

O serviço de voz em telefonia fixa, especialmente longa distância, está em queda, causando prejuízo às operadoras de longa distância em razão da forte competição que obriga à redução de preços e à existência de novas formas de comunicação de longa distância como e-mail e instant messaging.

As mudanças na estrutura do setor são acompanhadas de mudanças no perfil técnico e profissional da força de trabalho, assim como no número de trabalhadores: nos Estados Unidos, por exemplo, os cerca de 1 milhão de trabalhadores do Bell System aumentaram para aproximadamente 6 milhões espalhados por inúmeras pequenas e médias empresas bem como grandes multinacionais. A força de trabalho constituída no passado sobretudo por técnicos inclui agora um número cada vez maior de empregados em serviços de comercialização e vendas, assim como de especialistas em programação e em software. As previsões de emprego no setor de telecomunicações para o período de 1998-2008 indicam não só um crescimento no nível de profissionais especializados (especialistas em sistemas informáticos, engenheiros eletricistas e eletrônicos, 46,7\%) e de comercialização e vendas $(37,6 \%)$, mas também na área de gestão e direção, tendo em vista as novas formas de gestão geradas pela privatização e pela competição (37,3\%) (Katz et al., 2002, p. 4;
Monthly Labor Review, 1999, pp. 60-74; apud OIT, 2002, p. 115). ${ }^{8}$

Discutiremos a seguir as implicações dessas mudanças para os sindicatos.

\section{Os sindicatos nos países centrais}

As mudanças no setor produziram dramáticas conseqüências para os sindicatos, abalando a influência significativa que eles detiveram antes da quebra dos monopólios.

A desregulamentação começou nos Estados Unidos, onde dominava a AT\&T. Seguiu-se a privatização da British Telecom. ${ }^{9}$ As experiências norte-americana e inglesa constituíram-se modelos para outros países europeus, asiáticos e latino-americanos.

À medida que o setor se amplia e diversifica, caracterizando-se como indústria da informação, a influência dos sindicatos se reduz. As novas empresas e segmentos não possuem uma história de sindicalização e, muitas vezes, têm uma visão negativa sobre os sindicatos. Em conseqüência, a sindicalização no setor vem caindo mundialmente.

Considerando-se o caso norte-americano, a queda dos índices de sindicalização desde a desregulamentação foi significativa. Em 1984, quando da quebra do monopólio do Bell System, a AT\&T era o maior empregador privado do mundo com cerca de 1 milhão de empregados e o CWA, o maior sindicato de telecomunicações com cerca de 650 mil filiados (praticamente a totalidade dos operadores e técnicos, com expressiva representação entre os atendentes de serviço aos clientes). As negociações desenvolviam-se de forma centralizada e o acordo resultante tinha validade em âmbito nacional (Katz et al., 2002, p. 3). Desde então o número de sindicalizados, na AT\&T, vêm caindo drasticamente: nos últimos quatro anos caiu de 46.445 mil filiados, em 1998, para 31.522 mil, em 2001, e para cerca de 24 mil, em maio de 2002.

Apesar de significativo downsizing desde a desregulamentação, ${ }^{10}$ o número total de empregados na AT\&T aumentou 28\% no período de 19962000, enquanto o número de sindicalizados redu- 
ziu-se em 30\% no mesmo período. Tal redução é atribuída a diferentes fatores: incorporação de subsidiárias hostis aos sindicatos (como WorldCom); subcontratação e outsourcing;:"1 aumento de funções gerenciais (o que impede a sindicalização; em 1980, o percentual de gerentes na AT\&T era de 29\%, em 1995, de 50\%); e demissão de empregados sindicalizados. Por outro lado, o setor de telecomunicações está se expandindo em áreas de baixa sindicalização, como serviços de computação e informação, e, segundo alguns analistas, com poucas chances de se tornarem sindicalizadas no futuro (Batt e Keefe, 1999, pp. 127129; Katz e Darbishire, 2000, p. 56).

A redução no número de filiados significa para os sindicatos um declínio de poder e de receitas e, para os trabalhadores, uma crescente desigualdade nos salários (a diferença de salários entre trabalhadores sindicalizados e não sindicalizados nos Estados Unidos passou de 5\% para 20\%, no período de 1990-1995). A desigualdade salarial no setor foi também observada no interior de grupos demográficos. Os sindicatos sempre pressionaram por salários e condições de trabalho padronizados no interior e entre empresas; o declínio da sindicalização é visto como responsável pelas desigualdades dos ganhos. A queda nos índices de sindicalização, no entanto, não é homogênea para o setor como um todo; varia de acordo com áreas (longa distância, telemarketing, centros de atendimento, TV a cabo etc.) e empresas. Nas empresas regionais (baby Bells), nos Estados Unidos, por exemplo, $60 \%$ da forca de trabalho ainda é sindicalizada. Todavia, ao contrário do que acontece hoje, os sindicalizados do setor, nesse país, encontravam-se nas funções mais qualificadas (Keefe e Batt, 1997, pp. 52-56; Batt e Keefe, 1999, p. 130; Katz e Darbishire, 2000, p. 64; Batt, 2001, p. 427).

A tendência de crescimento das áreas de comunicação de dados e telefonia celular obriga os sindicatos a atuarem nesses segmentos. Entretanto, conforme mostra a Tabela 2, os sindicatos não têm sido bem-sucedidos pelo menos no que se refere às principais operadoras mundiais de celulares. O CWA apresenta melhores condições com mais de 15 mil filiados $^{12}$ na Cingular (oitavo lugar entre as maiores empresa internacionais), embora na Verizon Wireless (joint venture entre SBC Communications Inc. e Bell South, sexta maior companhia do mundo e maior operadora de celular nos Estados Unidos, com 29,4 milhões de usuários no final de 2001) conte apenas com cerca de 50 filiados, entre 30 mil empregados; na AT\&T, o número de sindicalizados é de cerca de 120, entre cerca de 30 mil empregados.

Torna-se cada vez mais difícil para os sindicatos atuarem num setor altamente diversificado, constituído por diversas pequenas e médias empresas, além de grandes multinacionais, algumas refratárias e/ou hostis aos sindicatos e que se utilizam de estratégias competitivas baseadas na precarização do trabalho. O que foi afirmado sobre a realidade dos sindicatos nos Estados Unidos - "os sindicatos precisam aprender a mobilizar uma base acostumada a vitórias relativamente fáceis" (Katz et al., 2002, p.4) - é também verdadeiro para o caso do Brasil.

Tabela 2

\section{Sindicalização nas Maiores Companhias de Celulares, 2001}

\begin{tabular}{lc}
\hline OPERADORA & SiNDICALIZADOS \\
\hline China & - \\
Vodafone (UK) & 525 \\
NTT DoCoMo (J) & $?$ \\
Orange (FR) & 490 \\
Deutsche Telekom & 100 \\
Verizon Wireless & 50 \\
Telefonica Moviles & 300 \\
Cingular & $15.100^{*}$ \\
AT\&T Wireless & 118 \\
KDDI (J) & 3.800 \\
BT Cellnet & 2.375 \\
\hline
\end{tabular}

*Inclui novos 4.100 sindicalizados, em 2002.

Fonte: CWA.

A diversificação do setor foi acompanhada pela diversidade das formas de emprego e práticas de trabalho, não apenas entre países e empresas, mas também no interior da própria empresa e dos 
grupos ocupacionais, resultado da segmentação do mercado (como ocorreu nos bancos comerciais). A empresa é dividida em departamentos de acordo com segmentos de mercado diferenciados pelo valor agregado dos serviços utilizados (residencial, negócios - pequenas e médias empresas e clientes corporativos). Quanto maior o valor agregado, melhor as condições de trabalho. Nos Estados Unidos, a AT\&T e outras empresas, como centros de atendimento, segmentam sua força de trabalho (em termos de qualificação, salário e condições de trabalho) de acordo com os segmentos de mercado (Batt e Keefe, 1999; Batt, 2001). Fenômeno similar ocorre na British Telecom, onde o contrato de trabalho varia de acordo com as divisões da empresa. No segmento residencial, as estratégias gerenciais quanto a condições de trabalho e relações industriais são mais restritas; no segmento de negócios, ao contrário, as estratégias são high road, envolvendo a participação de trabalhadores e a consulta aos sindicatos (Katz e Darbishire, 2000, p. 123). ${ }^{13}$

A individualização da remuneração é outra fonte de diversidade que, além de gerar desigualdades salariais entre empregados na mesma função, com as mesmas qualificações e no mesmo grupo de idade e educação, tende a desestimular a filiação dos empregados aos sindicatos (Katz e Darbishire, 2000, pp. 126-127).

A descentralização das negociações coletivas é, em grande parte, responsável pela diversidade referida. Nos Estados Unidos, assim como no Brasil, conforme verificar-se-á adiante, as negociações perderam o caráter nacional existente antes da desregulamentação. Apesar disso, até recentemente, os sindicatos norte-americanos tinham sido capazes de manter um padrão de negociação na AT\&T e nas operadoras regionais, principalmente no que se refere a aumento de salários, benefícios e segurança no emprego, a despeito das diferenças existentes entre as companhias quanto à política de salário variável. O acordo de 1998-2001, no entanto, estabeleceu diferenças acentuadas entre as companhias, em especial no que se refere a valores de pagamentos variáveis, planos de saúde e segurança de emprego. Os acordos em nível nacional perderam importância em escopo e substância.
A composição da força de trabalho tornouse também mais heterogênea. O setor inclui agora um número cada vez maior de profissionais, muitos dos quais sob forma de trabalhadores temporários, autônomos e empregados de agências de emprego (de acordo com estimativas do CWA, $30 \%$ dos trabalhadores atípicos do setor, nos Estados Unidos, insere-se nessa última categoria) (Batt et al., 1999). A organização desses empregados exige uma abordagem diferente comparada com a requerida por empregados regulares de uma empresa. Alguns segmentos de trabalhadores atípicos são profissionais altamente qualificados, desfrutam de boas condições de trabalho, incluindo boa remuneração e têm como foco de interesse a mobilidade e o aperfeiçoamento profissional, o que, em geral, é suprido pelas associações profissionais. Na maioria das vezes esses profissionais possuem uma visão estereotipada e negativa dos sindicatos e são contra a filiação.

No caso da Grã-Bretanha, após catorze anos de privatização, a British Telecom (BT), líder no mercado britânico (detendo 92\% do mercado local, 81\% do nacional e 70\% do internacional), adotou uma estratégia de redução de custo e do número de trabalhadores, reduzindo em cerca de $50 \%$ da força de trabalho no período de 19841998. Em conseqüência, os índices de filiação e de influência sindical declinaram ao mesmo tempo que cresceu o número de novos empregados não sindicalizados (Katz e Darbishire, 2000, p. 113; Batt e Darbishire, 1997, pp. 66-67). Verificouse também um aumento significativo da subcontratação, que passou de 4,2\%, em 1984, para 17,4 $\%$, em 1997. Os trabalhadores subcontratados que atuam em áreas importantes do setor como técnicos e operadores de centrais estão excluídos do contrato coletivo de trabalho. Em 1984, "menos de 1\% dos empregados tinham condições básicas de trabalho estabelecidas fora dos acordos coletivos. Em 1997, aquele percentual elevara-se para 29 \%." (Katz e Darbishire, 2000, p. 121).

Em 1992, os sindicatos de telecomunicações tentaram sem sucesso manter o processo de negociação em nível nacional, propondo o que foi denominado New Dialogue - um sistema de consulta baseado in today's commercial imperatives. 
A British Telecom (BT) rejeitou a proposta, considerando-a desnecessária diante da fragilidade sindical (Katz e Darbishire, 2000, p. 124).

Apesar desse quadro pouco otimista, os sindicatos têm desenvolvido esforços para melhorar sua posição. Ilustrativas são as experiências de colaboração sindicato/empresa, que visam a melhorar as condições de trabalho e de emprego no setor, ocorridas nos Estados Unidos, como, por exemplo, o acordo estabelecido entre o CWA e BellSouth no início dos anos de 1990; o programa conjunto de reorganização de funções criado pelo CWA e US West (1992-1993); o programa Workplace of the Future, entre Lucent and CWA, prevendo consulta entre gerentes e sindicato, em 1992; o acordo estabelecido em 1994 entre CWA e Nynex, quando "as partes negociaram o mais ousado acordo, jamais negociado no setor, entre sindicato e empregador, sobre estabilidade [...]", inclusive aumento de salários, retreinamento, acesso dos sindicatos às novas subsidiárias, em troca da redução de empregados. Essas experiências positivas foram, no entanto, desfeitas em meados dessa década ante as pressões da reestruturação (Batt e Darbishire, 1997, pp. 71-72; Batt e Keefe, 1999, pp. 130-133). ${ }^{14}$

A despeito dos insucessos, os sindicatos tentam superar as dificuldades criando estratégias de renovação. Novamente, o CWA é um bom exemplo: atuando de forma integrada em diferentes dimensões, o sindicato norte-americano teve alguns êxitos nas negociações coletivas, em parte graças à sua atuação política no sentido de apoiar os interesses das operadoras em matéria de regulação desde que estes coincidissem com os interesses dos trabalhadores..$^{15} \mathrm{O}$ CWA procura também fazer alianças entre o sindicato e o consumidor, desenvolvendo campanhas públicas em defesa do direito dos consumidores, chamando atenção para os interesses comuns entre consumidores e trabalhadores, sob o argumento de que boas condições de trabalho geram melhores serviços (Katz et al., 2002, pp. 15-16).

Ademais, o CWA mantém alianças internacionais, participando de campanhas conjuntas com sindicatos de telecomunicações, especialmente no Canadá e no México, comprometendo-se a "a defender os sindicatos e os direitos dos trabalhadores através de 'mobilizações conjuntas' envolvendo sindicalistas no México a na América do Norte" (Cohen e Early, 1999, p. 153). Integra ainda a organização mundial Working Group on Multinationals, que, em 1994, formulou um código de conduta para as companhias multinacionais de telecomunicações em que constam, entre outras, exigências como a de fornecer informações completas sobre as atividades internacionais da empresa às organizações de trabalhadores e reconhecimento dos sindicatos em nível internacional.

Estratégia importante para a renovação do sindicato foi a redefinição de sua identidade ao transformar-se de "sindicato de telecomunicações" em "sindicato da informação" por meio de fusões com outros sindicatos que representavam trabalhadores em um âmbito mais amplo do que o atual setor de informação: TV a cabo, internet, serviços de dados, informação, setor jornalístico e de publicação on line. Há ainda 80 mil empregados do setor público e de saúde que atuam nos serviços de atendimento a clientes de empresas aéreas ${ }^{16} \mathrm{e}$ empregados da Dow Jones da Bolsa de Valores de Nova York. Em 2000, o CWA acrescentou 130 mil filiados, resultado da fusão com o sindicato dos trabalhadores do setor elétrico, International Union of Electrical Workers (IUE), incluindo, assim, entre seus filiados, trabalhadores fabris do ramo de equipamentos de informação (Katz et al., 2002; Cohen e Early, 1999; CWA, 1999, www.cwa-union.org).

Em razão desses esforços, o CWA manteve e até expandiu o número de filiados em termos absolutos, já que em termos percentuais o decréscimo é significativo, com representação, em 2002, de cerca de 730 mil trabalhadores. Essas incorporações são importantes na medida em que abre caminho para a presença do sindicato entre os técnicos e profissionais do setor de informação. Além disso, há contribuições trazidas pelo conhecimento e experiência profissionais dos novos filiados, como, por exemplo,

[...] a utilização da Internet apoiada pelo conhecimento do pessoal do Sindicato de Jornais e da NABET (Associação Nacional de Empregados e Técnicos de Radiodifusão) cujos filiados possuem qualificação no trabalho com Internet $\mathrm{e}$ 
multimídia e um conhecimento muito mais sofisticado da indústria de comunicação. (Katz et al., 2002, p. 21).

São interessantes os casos Wash Tech e Alliance@IBM, cujos profissionais, altamente qualificados, trabalhando respectivamente para a Microsoft e empregados da IBM, diferentemente do que se supunha, manifestam interesse e atuam de forma efetiva para garantir sua representação coletiva. A Wash Tech organizou-se como associação em nível estadual (Seattle, Washington), filiandose ao CWA, em 1998. Os empregados dessa empresa possuem contrato temporário por meio de agências de emprego e, portanto, com direitos trabalhistas restritos (em 2000, o número de trabalhadores qualificados da Microsoft nessas condições era estimado em $35 \%$, sendo sete mil no país e 5.500 na região de Seattle). A associação tornou-se conhecida em razão do processo judicial que moveu contra a Microsoft, alegando desigualdade de tratamento dispensado pela empresa (sobretudo em termos de benefícios concedidos) aos funcionários de tempo integral e os subcontratados, que, segundo a petição, desempenhavam funções equivalentes. ${ }^{17}$ Os profissionais da IBM constituíram a Alliance@IBM em julho de 1999, filiando-se igualmente ao CWA, para protestar contra os cortes de benefícios pela IBM (Katz et al., 2002, p. 20).

O caso da WashTech parece sustentar empiricamente a tese de John Kelly ao afirmar que "a atividade e a organização coletiva em última análise derivam das ações dos empregadores que geram um senso de injustiça e ilegitimidade entre os empregados [...] eles devem atribuir a injustiça percebida ao empregador [...]" (Kelly, 1999, p. 44). Todavia, o número de trabalhadores filiados à WashTech é ainda pouco representativo (cerca de 250), considerando-se o número total de trabalhadores em situação atípica de emprego.

A organização de trabalhadores foi definida como um dos objetivos básicos do CWA. Os sindicatos locais são responsáveis por essa tarefa, desenvolvida de forma voluntária com base na comunicação face à face, sob o pressuposto de que o envolvimento dos trabalhadores é a chave para o sucesso das atividades sindicais.
Em termos de negociação coletiva, o sindicato tem conseguido obter resultados aceitáveis, mantendo e até mesmo elevando os ganhos em alguns itens, como aumento salarial, melhora nos planos de saúde e pensões ${ }^{18}$ eliminação de monitoramento secreto no trabalho e garantia de pelo menos quarenta horas de treinamento a todos os trabalhadores sindicalizados. A AT\&T e o CWA assinaram novo acordo coletivo em abril de 2002, com vigência para os dezoito meses seguintes. Embora não tenha havido avanços, o sindicato considerou a manutenção dos benefícios existentes (inclusive os relativos à segurança de emprego) ganhos em face dos objetivos iniciais da empresa de rediscutir o contrato.

O CWA vem tentando incluir nos acordos coletivos cláusulas relativas à garantia de emprego e de successorship (em caso de venda da empresa, o novo proprietário estaria obrigado a cumprir o contrato em vigor). Outro objetivo é o de limitar a subcontratação, ao garantir notificação antecipada e comitês conjuntos para discutir o problema, além de cláusulas que proíbem, limitam ou definem o número de trabalhadores e/ou tipo de trabalho a ser subcontratado. O sindicato tem também tentado incluir a cláusula denominada "Corporate Citizen", em que os fornecedores são notificados da importância que a corporação atribui ao cumprimento das leis trabalhistas e às boas relações com o sindicato.

Contudo, a despeito dos esforços, os sindicatos nos Estados Unidos e na Inglaterra vêm sofrendo grande hostilidade por parte dos empregadores. A experiência desses países não pode, no entanto, ser generalizada. Países como Alemanha, Itália e Suécia diferem dos Estados Unidos e do Reino Unido no que se refere à situação dos sindicatos em geral e, das telecomunicações, em particular.

Na Alemanha, a Deutsche Telekom (DT) fazia parte da estatal Deutsche Bundenpost, que incluía serviços postais, de telecomunicações e de caixa econômica até 1989, quando da Post Reform I, que separou a Telekom das outras companhias. Essa empresa deteve o monopólio dos serviços de telefonia e de televisão a cabo até a Post Reform II, em janeiro de 1995, que iniciou o processo de privatização; em 1996, a companhia 
vendeu 26\% das ações e, em 1998, foi completamente privatizada. O sindicato, Deutsche Postgewerkschaft (DPG), que fora muito influente, conseguiu mantê-la após a privatização, interferindo nas decisões que deram ritmo e definiram a natureza do processo. A relação sindicato/empresa tem sido de cooperação numa estratégia de ganhos mútuos. Em vez de promover demissões e adotar um modelo baseado no baixo custo do trabalho, a empresa tem se apoiado no aumento da receita - a tradicional medida de desempenho "linhas por empregado" foi substituída por "receita por empregado", fixada em DM 470,000. Tais resultados foram possíveis, em grande parte, devido às condições de regulação que favoreceram a posição da Telekom no mercado, o que reduziu as pressões competitivas.

Como monopólio estatal a DT era uma organização burocrática, hierárquica e centralizada. Após a privatização, a despeito da influência sindical, ocorreram mudanças significativas decorrentes desse processo, entre as quais são relevantes a racionalização e a reorganização do trabalho, a diversificação nos sistemas de emprego e de pagamentos, o crescimento do emprego atípico (nos anos de 1970, 15\% do emprego era atípico; na década de 1990, 33\%), a segmentação da força de trabalho, a descentralização do processo de decisão e de negociação coletiva e, por fim, a crescente diversidade em vários aspectos do setor. Os sindicatos sofreram declínio nos índices de filiação, ainda que em menor escala em relação a outros países, e perderam espaço para os conselhos de fábrica no processo de negociação (Ferner e Terry, 1997; Katz e Darbishire, 2000, pp. 208-210).

A Deutsche Telekom tenta ganhar maior flexibilidade valendo-se da descentralização da produção e de estratégias como fragmentação das negociações coletivas, esquemas de remuneração baseados em desempenho individual, ao que se opõem os sindicatos e os conselhos de fábrica. Uma das estratégias para escapar do controle sindical e obter maior flexibilização tem sido criar companhias subsidiárias.

Mesmo assim, os sindicatos têm conseguido garantir sua influência. Exemplo disso foi a reorganização do trabalho na DT ter sido negociada com o sindicato e também as subsidiárias terem sido obrigadas a negociar com ele acordos coletivos. Ele chegou a obter da empresa o compromisso de adotar um conjunto de princípios para definir um código de conduta em suas parcerias internacionais "assegurando que as relações usuais na Alemanha entre empregador e empregado sejam reconhecidas e aceitas em todos as subsidiárias e setores de negócios em que a Deutsch Telekon esteja envolvida, assim como seus parceiros no mundo e em demais empresas na Alemanha". (citado por Cohen e Early, 1999, p. 160). Portanto, diferentemente do que ocorreu nos Estados Unidos e na Inglaterra, as novas empresas na Alemanha relacionam-se com os sindicatos que, juntamente com os conselhos de fábrica, garantem nas subsidiárias condições de trabalho semelhantes às da Telekom.

Ademais, alguns fatores institucionais atuam como freios ao individualismo propugnado pelas empresas. O modelo alemão garantiu à Telekom uma posição favorável no mercado, liberando a empresa de pressões competitivas demasiadas: a empresa ainda mantém o controle da companhia de TV a cabo, a maior do mundo (Batt e Darbishire, 1997, p. 75). Por outro lado, a existência de uma legislação que garante direitos aos conselhos de fábrica impede as empresas de anularem a representação coletiva dos trabalhadores. O dualismo do sistema alemão, sem abdicar dos acordos coletivos centralizados que definem parâmetros de negociação, permite um grau de flexibilidade necessário para atender às situações particulares. ${ }^{19}$ Todavia, os estudos constatam um deslocamento das negociações em direção ao local de trabalho, o que resulta em maior influência para os conselhos de fábrica e maior possibilidade de concessões pelos trabalhadores, introduzindo, também, maior diversidade nas situações de trabalho, o que provoca um aumento da pressão sob os sindicatos. Aumenta, pois, o número de atores e a diversidade de situações em relação às práticas de emprego e de trabalho.

Mesmo sob um padrão geral de contrato, as subsidiárias gozam de maior flexibilidade ao negociar com os conselhos de fábrica. Outros sindicatos que não o DPG estão agora representando os trabalhadores nas novas empresas de telecomuni- 
cações; o resultado disso é a diversidade dos contratos (Katz e Darbishire, 2000, p. 214). Portanto, apesar da capacidade do DPG de manter a coordenação nas relações entre conselhos de fábrica e empresas e das negociações nas subsidiárias, bem como manter sua representação nos comitês das empresas, a descentralização e a variabilidade estão também presentes no setor das telecomunicações alemão. Por outro lado, a despeito de sua influência, o DPG não conseguiu evitar aspectos danosos aos trabalhadores como, por exemplo, queda do nível de emprego, formas de remuneração por desempenho, crescimento das desigualdades salariais, assim como maior desequilíbrio na distribuição entre lucros e salários (Katz e Darbishire, 2000).

De modo geral, observa-se que mesmo em condições favoráveis, como é o caso dos sindicatos alemães se comparados com a situação dos norte-americanos e britânicos, os sindicatos de telecomunicações nos países centrais se encontram sob pressão devido ao maior número de atores e à crescente diversidade nas práticas de trabalho no setor, que, no passado, foi bastante homogêneo e centralizado.

\section{O caso do Brasil}

O processo de reestruturação das telecomunicações, como já foi referido, é um fenômeno mundial, que atinge, indistintamente, os países industrializados da América do Norte, da Europa, da Ásia e da América Latina. Entretanto, a natureza, a motivação e os arranjos desses processos diferem entre si. Uma diferença fundamental diz respeito à motivação, ou seja, países como os Estados Unidos e a Grã-Bretanha implementaram a reforma do setor de telecomunicações a partir de pressões internas originadas nos grupos empresariais identificados com as grandes corporações multinacionais, bem como de pressões oriundas de setores industriais ligados à indústria produtora de equipamentos para o setor de telecomunicações (indústria informática e aeroespacial), em busca de mercados e da consolidação de hegemonia tecnológica. ${ }^{20}$
Em países "periféricos", como os da América Latina, onde os monopólios no setor de telecomunicações eram, em geral, ou de propriedade estatal ou controlados pelo Estado, a quebra dos monopólios decorre, principalmente, da incapacidade de os governos financiarem o desenvolvimento do setor em razão da crise fiscal que abala as finanças desses países desde meados dos anos de 1970, com agravamento na década seguinte. No Brasil, o nível de investimento no setor caiu de US\$ 3,5 bilhões em 1973-1979 para US\$ 2,4 bilhões no período de 1980-1989 (Costa, s.d., p. 12).

A reestruturação nesses países assume um caráter defensivo e de controvérsia política, pois envolve soluções que implicam a transferência total ou parcial de bens públicos, em muitos casos, para o capital estrangeiro. Os opositores interpretam tais interferências como uma afronta à soberania nacional. Como afirmam Katz e Darbishire: "os países diferem em relação a quanto se encontram abertos à competição internacional e a quanto a competição internacional constitui-se em nova fonte de pressão" (2000, p. 4).

No Brasil, o envolvimento do governo no setor de telecomunicações é relativamente recente, já que a empresa estatal Embratel foi criada em 1965. Até então, grande parte (68\%) dos serviços de telecomunicações eram providos pela Companhia Telefônica Brasileira (CTB), firma canadense, subsidiária da Canadian Traction Light and Power Company; o restante era provido de forma fragmentária, técnica e gerencialmente, deficiente por cerca de 800 pequenas firmas privadas. A qualidade dos serviços era bastante insatisfatória, apresentando uma das mais baixas densidades no mundo (Hobday, 1990, p. 90).

Em 1962, o governo estabeleceu o controle sobre os serviços de telecomunicações por meio do Código Brasileiro de Telecomunicações. O Ministério das Comunicações foi criado em 1967; em 1972, a Telebrás, a bolding estatal que completava o Sistema Brasileiro de Telecomunicações, integrado por a) 24 companhias pertencentes aos Estados da federação, encarregadas dos serviços em seus territórios; b) Embratel, encarregada da comunicação interestadual e internacional, bem como de serviços especiais, como comunicação 
de dados; e c) o Centro de Pesquisa e Desenvolvimento (CPqD).

Nos anos de 1970, a Telebrás cresceu rapidamente, utilizando-se, sobretudo, de recursos obtidos pelo Fundo Nacional de Telecomunicações (fundo de investimento gerado por meio de imposto de 30\% sobre serviços de telecomunicações) ${ }^{21} \mathrm{O}$ crescimento da inflação na década seguinte levou os governos ao controle de preços das tarifas públicas, o que resultou em defasagem tarifária e, em conseqüência, na queda de arrecadação e na incapacidade de investimento. Isso gerou não só o atraso na modernização da infra-estrutura básica, mas também dificuldades para a ampliação da digitalização da rede e a instalação de cabos de fibra ótica, ocasionando incapacidade de atendimento da demanda de serviços mais sofisticados, como fax, telefonia móvel, serviços de multimídia, videoconferência, paging, entre outros (Carvalho Neto, 1998, p. 109). A situação da Telebrás agravou-se nos anos de 1990: baixo índice de atendimento da demanda por serviços de telecomunicação (seis linhas telefônicas por 100 habitantes) e baixos padrões de qualidade e de produtividade (onze empregados por 1000 habitantes). Havia, também, uma acentuada distorção gerada pelo sistema na distribuição de telefones entre as diferentes camadas da população. Assim, em 1998, os 16\% da população de mais alta renda possuíam $81 \%$ dos telefones residenciais, com uma média de duas linhas telefônicas por família, pagando um valor simbólico de R $\$ 0,44$ como tarifa mensal de assinatura (Paste, Anatel, 2000, p. 18). Cinqüenta e dois por cento da população de baixa renda possuíam apenas $2 \%$ dos telefones residenciais, com média de uma linha telefônica por 100 famílias (Anatel, 1998, citado na revista Veja, 28.7.1998, p. 107). ${ }^{22}$ Além disso, a empresa, que requeria uma boa capacidade administrativa e de planejamento tecnológico, via-se envolvida com problemas de disputas políticas por cargos (Costa, 1996; Albuquerque et al., 1999).

O Sistema Telebrás foi privatizado em julho de 1998, dividindo o país em três regiões, NorteLeste, Centro-Oeste-Sul e parte da Região Norte e São Paulo, cuja exploração de serviço de telefonia fixa coube a três operadoras - respectivamente, Telemar, Brasil Telecom e Telefônica de Espanha e a de longa distância, Embratel/WorldCom. O modelo brasileiro de privatização estruturou-se em termos de duopólio: a) as empresas concessionárias originárias do Sistema Telebrás operam como serviço público e são obrigadas a cumprir metas de universalização, continuidade e qualidade impostas pela agência reguladora, Anatel; e b) as empresas competidoras ("empresas-espelho", cujo ingresso no mercado foi liberado em dezembro de 1999), não estando sujeitas às metas impostas às concessionárias, operam com tarifas liberadas. Estas últimas podem utilizar tecnologia Wireless Local Loop (vedada às concessionárias), com baixos custos de instalação e de manutenção e contam com uma força de trabalho ajustada a suas necessidades. Carecem, no entanto, do mercado cativo das concessionárias ${ }^{23} \mathrm{e}$, como desafio, devem construir estratégias para atrair clientes. As empresas concessionárias e as autorizadas não poderiam prestar serviço em outra região antes de 31 de dezembro de 2003 e 2002, respectivamente, a não ser que antecipassem as metas impostas pela agência reguladora.

A privatização alterou profundamente o contexto das telecomunicações, no Brasil. O nível de investimento no período de 1980/1989 era de US\$ 2,4 bilhões, e a teledensidade para a telefonia fixa (número de acessos telefônicos por 100 habitantes) era, em 1990, de 7,1 bilhões. No final de 2001, essa taxa quadruplicou, chegando a 28,2 bilhões. A teledensidade referente à telefonia móvel também cresceu significativamente: no final de 1998, era de 4,5 bilhões, passando para 14,0, em 2001; a estimativa é que chegue, em 2005, a 32,6 bilhões (o Rio Grande do Sul já possui essa densidade e o Rio de Janeiro e o DF, já ultrapassam) (Paste, Anatel, 2000; Anatel, 2003)..$^{24}$

As principais companhias operadoras - Telemar, Brasil Telecom, Telefônica/Telesp e Embratel obtiveram crescimento expressivo da receita líquida de vendas e/ou serviços desde 1999 (ver Tabela 3), embora tenha havido redução do lucro líquido (exceção da Brasil Telecom, que optou por não adiantar metas) em razão das dificuldades econômicas gerais que se refletiram no setor em 
termos de aumento da inadimplência, cancelamento de linhas, aumento da competição e queda da taxa de utilização.

O aumento da produtividade do trabalho (número de linhas em serviço por empregado) tem sido extraordinário: na Brasil Telecom, de 1999 a 2002, o aumento foi de 260,7\%, passando de 471 para 1.699 (Tabela 3); na Telefônica/Telesp, o aumento da produtividade do trabalho, de 1999 até o final de 2002, foi de 131,7\%, passando

Tabela 3

Indicadores Físicos e Financeiros das Empresas de Telefonia Fixa (R\$ 1000)

\begin{tabular}{|c|c|c|c|c|c|c|}
\hline $\begin{array}{l}\text { Companhias e } \\
\text { indicadores }\end{array}$ & 1999 & 2000 & 2001 & 2002 & $\begin{array}{r}\text { Variação } \\
2001-2002\end{array}$ & $\begin{array}{r}\text { Variação } \\
1999-2002\end{array}$ \\
\hline \multicolumn{7}{|l|}{ Telemar } \\
\hline Receita Líq. de Vendas/Serviços & 6214938 & 8119963 & 10103066 & 11874000 & $17,5 \%$ & $91,1 \%$ \\
\hline Despesas com Pessoal & 721537 & 731000 & 906000 & 801000 & $-11,5 \%$ & $11,1 \%$ \\
\hline Lucro Líquido & 95686 & 709407 & 140378 & -415598 & - & - \\
\hline N. de Linhas em Serviço & 9723 & 11819 & 14816 & 15100 & $1,9 \%$ & $55,3 \%$ \\
\hline Linhas em Serviço/Empregados & 427 & 560 & 984 & 1599 & $62,3 \%$ & $274,5 \%$ \\
\hline Número de Empregados & 24563 & 21090 & 15056 & 9441 & $-37,3 \%$ & $-160,1 \%$ \\
\hline \multicolumn{7}{|l|}{ Brasil Telecom } \\
\hline Receita Líq. de Vendas/Serviços & 3058478 & 4510168 & 6158408 & 7071000 & $14,8 \%$ & $133,2 \%$ \\
\hline Despesas com Pessoal & 482217 & 451416 & 474300 & 402700 & $-45,1 \%$ & $-16,5 \%$ \\
\hline Lucro Líquido & 218022 & 409613 & 261002 & 443000 & $69,7 \%$ & $103,2 \%$ \\
\hline N. de Linhas em Serviço & 4718 & 7446 & 8638 & 9465 & $9,6 \%$ & $100,6 \%$ \\
\hline Linhas em Serviço/Empregados & 471 & 700 & 1095 & 1699 & $55,1 \%$ & $260,7 \%$ \\
\hline Número de Empregados & 10016 & 10642 & 7890 & 5571 & $-29,4 \%$ & $-44,4 \%$ \\
\hline \multicolumn{7}{|l|}{ Telefonica (Telesp) } \\
\hline Receita Líq. de Vendas/Serviços & 5295508 & 7309683 & 8983078 & 10088114 & $12,3 \%$ & $90,5 \%$ \\
\hline Despesas com Pessoal & 116867 & 164838 & 139953 & 124747 & $-10,7 \%$ & $6,9 \%$ \\
\hline Lucro Líquido & 735834 & 1470000 & 1576305 & 1075900 & $-31,8 \%$ & $46,3 \%$ \\
\hline N. de Linhas em Serviço & 8049 & 10331 & 12283 & 12551 & $2,2 \%$ & $55,9 \%$ \\
\hline Linhas em Serviço/Empregados & 567 & 770 & 1166 & 1314 & $12,6 \%$ & $131,7 \%$ \\
\hline Número de Empregados & 14196 & 13414 & 10529 & 9516 & $-9,6 \%$ & $-32,9 \%$ \\
\hline \multicolumn{7}{|l|}{ Embratel } \\
\hline Receita Líq. de Vendas/Serviços & 5183927 & 6714508 & 7460956 & 7107078 & $-4,7 \%$ & $37,1 \%$ \\
\hline Despesa de Pessoal & 66772 & 100921 & 99202 & 118075 & $19,2 \%$ & $78,7 \%$ \\
\hline Lucro Líquido & 411631 & 577090 & -556671 & -626000 & - & - \\
\hline N. de Linhas em Serviço & - & - & - & - & - & - \\
\hline Linhas em Serviço/Empregados & - & - & - & - & - & - \\
\hline Número de Empregados & 10244 & 12000 & 12017 & 12012 & $-0,05 \%$ & $17,2 \%$ \\
\hline
\end{tabular}

* Resultados em 31/12/2002.

Fonte: Relatórios Anuais das empresas. 
de 567 para 1.314. Esse crescimento deve-se principalmente à ampliação das plantas e à concomitante redução do número de empregados.

Apesar dos resultados positivos, as telecomunicações no Brasil passam por um momento de transição, marcado por incertezas. Prevê-se que ao final do processo de liberalização do mercado haverá uma nova configuração de empresas, resultado de fusões, alianças e parcerias. Nesse contexto, as empresas também enfrentam desafios e incertezas ao que respondem com formas mais duras em sua relação com os trabalhadores.

Quanto aos sindicatos, as implicações do processo de privatização/liberalização têm similaridades ao que ocorreu nos Estados Unidos, sobretudo no que se refere à transformação da base de trabalhadores de uma empresa monopólica (estatal, no caso do Brasil), sob negociações coletivas centralizadas, para uma base de trabalhadores dispersos por múltiplas empresas privadas, controladas por empresas estrangeiras de origens distintas. Os sindicatos são surpreendidos com a enorme fragmentação e heterogeneidade que caracteriza hoje o setor em contraste com a homogeneidade do passado.

Nas condições atuais, essa fragmentação é danosa para os sindicatos, tanto em termos da descentralização das negociações coletivas, como da dificuldade de recrutar trabalhadores dispersos geograficamente. Com a privatização da Telebrás, as negociações coletivas, quando ocorrem, acontecem entre empresas e sindicatos locais. Com o enfraquecimento da Federação Nacional (Fittel) perdeu-se a referência nacional. Nesse sentido, os sindicatos brasileiros tiveram menos êxito do que os norte-americanos, já que estes haviam conseguido garantir negociações abrangentes no nível da AT\&T e das Bells regionais. No Brasil, a diversificação de empresas, a descentralização e, portanto, a variedade de resultados passaram a ser, após a privatização, temas centrais de discussão, o que causa certa perturbação e revela o enfraquecimento dos sindicatos, despreparados para enfrentar essa realidade. Assim como ocorre nos países centrais, o fenômeno da fragmentação e da diversidade também se manifesta como segmentação do mercado de trabalho, com diferenças muito nítidas nos perfis de trabalhadores do setor, entre e no interior das empresas, tornando difícil a tarefa de comunicação e mobilização dos sindicatos. Segundo o depoimento de um líder sindical, a segmentação dos trabalhadores traz inúmeras dificuldades para a mobilização dos empregados, desde questões relativas às pautas, que não podem ser as mesmas para todos os segmentos, até o tipo de linguagem e de abordagem a ser utilizado: "não é possível tratar da mesma maneira trabalhadores de empreiteiras e empregados de empresas de telefonia celular". Como afirma Sennett: "A rotinização tornou-se uma arena em que os trabalhadores podem afirmar suas próprias demandas, uma arena de empoderamento" (1998, p. 43).

Há, portanto, necessidade de um aprendizado sobre como negociar com o setor privado sem a "proteção" do Estado. A experiência anterior era bastante diferente, ainda que não estivesse livre de conflito, a negociação ocorria, muitas vezes, no âmbito do Congresso Nacional ou do Ministério, envolvendo a influência de políticos e atores no governo. Esse tipo de relação sindicato/empresa estava também presente no antigo Bell System: "Com uma história de relações de trabalho cooperativas no velho sistema Bell, os sindicatos precisaram aprender a mobilizar seus filiados acostumados a vitórias relativamente fáceis" (Katz et al., 2002, pp. 3-4).

Os sindicatos de telecomunicações no Brasil constatam o declínio nos índices de filiação e a conseqüente perda de arrecadação financeira. Segundo informação de um líder sindical, em dois anos, os sindicatos perderam em média cerca de $40 \%$ de sua receita. Sua situação financeira poderá piorar se as empresas deixarem de liberar os dirigentes sindicais, como é possível que aconteça.

A redução de pessoal nas operadoras deverá continuar, já que as empresas necessitam aumentar rapidamente a produtividade para compensar os altos investimentos realizados. Aposentadorias, demissões voluntárias e involuntárias persistem, e a tendência é de aumento do número de empregados terceirizados mesmo em atividades-fim. No período de 1999-2002, a Telemar reduziu em 160,1\% sua força de trabalho, enquanto a Brasil Telecom e a Telefônica reduziram em $44,4 \%$ e 32,9\%, respec- 
tivamente; a Embratel foi a única a aumentar o número de empregados, em 17,2\% (Tabela 3). Observa-se uma pulverização dos trabalhadores, muitas vezes ocupados em empresas subcontratadas de pequeno porte e/ou em áreas incluídas em outras categorias que não as abrangidas pelos sindicatos de telecomunicações, como no caso do telemarketing, em que os trabalhadores podem se filiar ao sindicato do comércio, ou nos caso dos trabalhadores de manutenção de cabos, que podem se filiar ao sindicato da construção civil, cuja lógica e funcionamento são muito diferentes da dos sindicatos de telecomunicações.

As dificuldades de recrutamento estendemse aos novos empregados, que se constituem em grande parte de mão-de-obra jovem, com escolarização elevada e distantes da cultura sindical. Ademais, há uma maior restrição das empresas à ação sindical. Por outro lado, deve-se lembrar das dificuldades enfrentadas pelos próprios sindicatos, que dizem respeito à necessidade de se livrar da cultura do sindicalismo estatal e à ausência de organização nos locais de trabalho, problemas que decorrem, entre outros aspectos, de condições adversas, como carência de recursos, falta de qualificação de seus quadros e temor do desemprego por parte dos trabalhadores.

Esse quadro indica as tendências gerais da relação entre os sindicatos de telecomunicações no Brasil e as empresas, mas essa relação é muito diversificada, confirmando as constatações de Katz e Darbishire (2000) no estudo sobre sindicatos de telecomunicações em diferentes países.

Considerando-se o exemplo da Companhia Riograndense de Telecomunicações (CRT)/Brasil Telecom, concessionária regional (Rio Grande do Sul) e primeira companhia telefônica brasileira a ser privatizada (dezembro de 1996), ${ }^{25}$ é possível comparar o conteúdo dos acordos coletivos assinados entre a empresa e o sindicato no período anterior e posterior à privatização. O Quadro 1 resume os pontos principais desses acordos entre1994/1995 e

\section{Quadro 1}

Acordos Coletivos de Trabalho: CRT (1994/1995-2000/2002)

\begin{tabular}{|c|c|c|c|c|c|c|}
\hline Período/Itens & 1994-1995 & 1995-1996 & $1996 / 97$ & $1997 / 98$ & $1999 / 2000$ & $2001 / 2002$ \\
\hline \multicolumn{7}{|l|}{ REMUNERAÇÃO } \\
\hline $\begin{array}{l}\text { Reajuste } \\
\text { salarial }\end{array}$ & $\begin{array}{l}\text { Variação cf. índice } \\
\text { oficial da inflação }\end{array}$ & Mantida & $\begin{array}{l}\text { 10,8\% (acima índice } \\
\text { de inflação) } \\
\text { Inclui produtividade }\end{array}$ & $\begin{array}{l}\text { 1,5\% (abaixo ín- } \\
\text { dice inflação) }\end{array}$ & $\begin{array}{l}\text { Abono: } \mathrm{R} \$ 917+ \\
26 \% \text { salário }\end{array}$ & $\begin{array}{l}\text { Até } \mathrm{R} \$ 6.000,6 \% \\
\text { acima de } \mathrm{R} \$ \\
6.000,4 \% \text { incor- } \\
\text { porp. ao salário; } \\
\text { abono: } \mathrm{R} \$ 825 \mathrm{a} \\
\text { todos empregados }\end{array}$ \\
\hline Produtividade & $\begin{array}{l}5 \% \text { sobre salário já } \\
\text { reajustado }\end{array}$ & $\begin{array}{l}2 \% \text { sobre sal., con- } \\
\text { dic. a gastos c/ } \\
\text { pessoal; não incor- } \\
\text { por. ao salário }\end{array}$ & $\begin{array}{l}\text { Incluída no reajuste } \\
\text { do salário }\end{array}$ & Extinta & Extinta & Extinta \\
\hline $\begin{array}{l}\text { Participação } \\
\text { nos lucros e/ou } \\
\text { resultados }\end{array}$ & & & & & $\begin{array}{l}80 \% \text { sal e } 20 \% \\
\text { fixo. Ante- } \\
\text { cip.R } \$ 1.200 \text { se me- } \\
\text { tas até abr } / 2000\end{array}$ & $\begin{array}{l}80 \% \text { salário e } 20 \% \\
\text { fixo. Limite } 1,2 \\
\text { sal.; Metas alcan- } \\
\text { çadas ago/01: } 1,8 \\
\text { sal. todos }\end{array}$ \\
\hline Anuênio & $\begin{array}{l}\text { Adicional tempo de } \\
\text { serviço ( } 1 \% \text { salário) }\end{array}$ & Mantida & Mantida & Mantida & Extinta & Extinta \\
\hline $\begin{array}{l}\text { Gratificação de } \\
\text { férias }\end{array}$ & $\begin{array}{l}70 \% \text { salário no iní- } \\
\text { cio férias }\end{array}$ & Mantida & Mantida & Mantida & $\begin{array}{l}\text { 34\% salário, cf. } \\
\text { CLT }\end{array}$ & Manteve \\
\hline
\end{tabular}




\begin{tabular}{|c|c|c|c|c|c|c|}
\hline Período/Itens & 1994-1995 & 1995-1996 & $1996 / 97$ & $1997 / 98$ & $1999 / 2000$ & $2001 / 2002$ \\
\hline \multicolumn{7}{|l|}{ EMPREGO } \\
\hline $\begin{array}{l}\text { Jornada de } \\
\text { trabalho }\end{array}$ & $\begin{array}{l}36 \text { hs telefon e em- } \\
\text { pregados com au- } \\
\text { diofone e terminal } \\
\text { vídeo; } 40 \text { hs. demais } \\
\text { empregados }\end{array}$ & Mantida & Mantida & Mantida & Mantida & Mantida \\
\hline Horas extras & $\begin{array}{l}\text { Adicional } 50 \% 2 \text { pri- } \\
\text { meiras hs. } 100 \% \text { para } \\
\text { hs. subseqüentes }\end{array}$ & Mantida & $\begin{array}{l}\text { Adicional 50\%, cf. } \\
\text { CLT }\end{array}$ & Mantida & Mantida & Mantida \\
\hline $\begin{array}{l}\text { NT/Programa } \\
\text { de capacitação, } \\
\text { realocação e } \\
\text { desenvolvi- } \\
\text { mento profis- } \\
\text { sional }\end{array}$ & $\begin{array}{l}\text { Não dispensará em- } \\
\text { preg. por introdu- } \\
\text { ção NT; recapacita- } \\
\text { ção e realocação } \\
\text { dos atingidos NT }\end{array}$ & $\begin{array}{l}\text { Recapacitação e } \\
\text { realocação empre- } \\
\text { gados atingidos } \\
\text { por NT }\end{array}$ & Mantida & Mantida & $\begin{array}{l}\text { Programa de ca- } \\
\text { pacitação e de- } \\
\text { senvolvimento } \\
\text { profissional para } \\
\text { empregados atin- } \\
\text { giram NT/auto- } \\
\text { mação }\end{array}$ & Manteve \\
\hline $\begin{array}{l}\text { Mão-de-obra } \\
\text { subcontratada/ } \\
\text { terceirização }\end{array}$ & $\begin{array}{l}\text { Reduzirá gradativa- } \\
\text { mente subcontrata- } \\
\text { ção mão-de-obra }\end{array}$ & Mantida & Mantida & Mantida & Extinta & Extinta \\
\hline \multicolumn{7}{|l|}{ GESTÃO } \\
\hline $\begin{array}{l}\text { Avaliação de- } \\
\text { sempenho/ } \\
\text { promoção }\end{array}$ & $\begin{array}{l}\text { Critérios previamen- } \\
\text { te divulgados a to- } \\
\text { dos empregados }\end{array}$ & Mantida & Mantida & Mantida & Extinta & Extinta \\
\hline \multicolumn{7}{|l|}{$\begin{array}{l}\text { RELACÕES } \\
\text { SINDICAIS }\end{array}$} \\
\hline $\begin{array}{l}\text { Liberação de } \\
\text { dirigentes }\end{array}$ & $\begin{array}{l}\text { Liberará todos os } \\
\text { membros diretores } \\
\text { SINTTEL e FITTEL }\end{array}$ & Mantida & Mantida & Mantida & $\begin{array}{l}\text { Até } 12 \text { emprega- } \\
\text { dos com remune- } \\
\text { ração }\end{array}$ & $\begin{array}{l}\text { Manteve } \\
\text { Será reexaminado } \\
\text { em nova eleição }\end{array}$ \\
\hline Comissões & $\begin{array}{l}\text { Sinttel e CRT, fun- } \\
\text { ções consultiva e } \\
\text { deliberativa }\end{array}$ & Extinta & Extinta & Extinta & \begin{tabular}{|l} 
Sinttel e CRT c/ \\
objetivo de conci- \\
liar conflitos cole- \\
tivos e/ou indivi- \\
duais de trabalho
\end{tabular} & Manteve \\
\hline
\end{tabular}

Fonte: Elaboração a partir dos Acordos Coletivos de Trabalho firmados entre o SINTTEL e CRT (1994-2000).

2000/2002, evidenciando as mudanças ocorridas após a privatização. O caso da CRT pode ser tomado como exemplo, já que antes da privatização os acordos eram muito similares em todo o Sistema Telebrás. Após a privatização, os acordos passaram a variar significativamente entre as companhias, o que indica os resultados da descentralização do processo de barganha (Quadro 2).

O exame dos acordos firmados entre a CRT e o Sinttel/RS (Sindicato dos Trabalhadores em
Empresas de Telecomunicações e Operadores de Mesas Telefônicas no Estado do Rio Grande do Sul) no período de 1994/1995 a 2000/2002 também evidencia as mudanças ocorridas após a privatização, conforme mostra o Quadro 1.

Em relação à remuneração, os empregados contavam com uma recomposição salarial anual baseada em reajustes lineares de acordo com a variação do índice oficial de inflação. Havia outros benefícios incorporáveis ao salário, como o 
percentual correspondente a ganhos de produtividade, anuênios ( $1 \%$ do salário por tempo de serviço) e gratificação de férias ( $70 \%$ da remuneração fixa mensal). Preparando-se para a privatização, a empresa passou a impor restrições a alguns dos benefícios referidos: por exemplo, o adicional de produtividade, que no acordo firmado em 1994/1995, chegara a 5\% do salário, caiu para 2\% no acordo de 1996/1997, deixou de ser incorporado ao salário e sua concessão ficou condicionada ao valor das despesas com custos com pessoal. No último acordo firmado antes da privatização, a "produtividade" desaparece como cláusula, sendo incluída no percentual do reajuste salarial. Alterações mais significativas verificam-se após a privatização: a "produtividade" passou a ser negociada no âmbito da PLR (Participação nos Lucros e Resultados); desapareceu a cláusula relativa a anuênios; o valor da gratificação de férias foi rebaixado de $70 \%$ do salário para $34 \%$, conforme previsto em lei; os reajustes salariais deixaram de ser regidos por índices de variação da inflação, ou mesmo desapareceram como tal, sendo substituídos por abonos. No último acordo firmado entre o Sinttel/RS e a CRT (2001-2002) o reajuste salarial voltou a ser incorporado ao salário, mantendo-se a concessão de um abono. Observa-se, nesse acordo, uma sensível melhora nos ganhos monetários, comparando-se com os outros acordos pós-privatização. A significativa expansão do mercado de telefonia, o aumento da concorrência, bem como os esforços para antecipar metas, parecem ter contribuído para tal resultado.

A negociação da PLR no setor de telecomunicações iniciou-se apenas a partir de $2000 \mathrm{e}$ como PR (Participação nos Resultados). ${ }^{26}$ Os sindicatos recusavam-se a negociar a PLR por razões de ordem ideológica, pois acreditavam que aceitar essa forma de remuneração significava a submissão aos princípios capitalistas. A difusão dessa prática, no entanto, obrigou-os a rever sua posição (Carvalho Neto, 1998, p. 170). ${ }^{27}$

A supressão de itens, como reajustes salariais regidos por índices de inflação oficial, gratificação de férias, anuênios, a implementação da PLR e a concessão de abonos introduziram um percentual significativo de componente variável na remunera- ção dos trabalhadores em telecomunicações. Dessa forma, as empresas visam a enfrentar mudanças tecnológicas constantes e a alta competição que se estabelece no setor, assim como a garantir o comprometimento dos trabalhadores com suas metas.

O acordo firmado entre a CRT e o Sinttel em relação à PLR considerou como indicador "resultados" e não "lucros", por decisão do sindicato. ${ }^{28}$ Os termos dos acordos contêm aspectos favoráveis aos trabalhadores (Quadro 1). No acordo de 1999-2000, o valor básico a ser distribuído (pagamento anual) foi de $1,2 \%$ da remuneração, sendo $20 \%$ constituído de parcela fixa, $\mathrm{R} \$ 435,00$, e $80 \%$, proporcional ao salário de cada empregado. Foi negociado também um adiantamento no valor de $\mathrm{R} \$ 1.200,00$ condicionado ao cumprimento das metas até abril de 2000. Na mesma ocasião foi concedido abono salarial a todos os empregados, no valor de R\$917,00, acrescido de 26\% do salário de cada empregado. No acordo firmado de 2001, os ganhos estabelecidos passaram a ser condicionados à antecipação de metas, tendo em vista a necessidade de a empresa obter a certificação da Anatel para atuar em outras regiões do país, conforme consta na cláusula primeira, parágrafos primeiro e segundo do referido acordo:

Se a Empresa Brasil Telecom receber da Anatel a Certificação pelo cumprimento da Antecipação das Metas de Universalização podendo, assim, operar em outras regiões do mercado de telecomunicações, o valor acima de 1.2 salários passará para 1.8 salários como incentivo e premiação por esse esforço conjunto de todos os empregados na obtenção dessa Certificação.

Se, entretanto, a Empresa Brasil Telecom não obtiver essa Certificação da Anatel, nada será pago a título de Participação nos Resultados de 2001, ainda que a CRT tenha atingido suas metas. (Acordo Coletivo de Trabalho para o Estabelecimento de Programa de Participação nos Resultados para 2001, Sinttel/RS-CRT Brasil Telecom, p. 2).

Registre-se o tom ameaçador do parágrafo segundo, em que as metas da empresa assumem o significado de imposição: ou são atingidas em sua totalidade ou o acordo perde validade. 
Os valores pagos como PR e como abonos constituem ganhos para os trabalhadores tendo em vista as dificuldades presentes no mercado de trabalho, ainda que pagos na forma de remuneração variável. Contudo, deve-se reconhecer que a remuneração variável baseada em lucros e resultados transfere os riscos dos empresários para os trabalhadores, já que a remuneração destes passa a variar conforme a situação econômica da empresa, sem que lhes seja transferida a capacidade de gestão e decisão.

Mais significativo talvez do que os ganhos monetários seja a possibilidade que esses acordos oferecem de o sindicato ter acesso a fontes e dados da empresa, prerrogativa negada aos sindicatos mesmo quando as empresas encontravam-se sob o controle estatal (Carvalho Neto, 1998, p. 169). No caso em análise, a decisão de realizar acordos relacionados à PR resultou na constituição de uma comissão integrada por membros do sindicato e da empresa com a incumbência de acompanhar o andamento do cumprimento dos indicadores com acesso às fontes e dados necessários. Embora a formação desse tipo de comissão com a participação dos sindicatos seja prevista em lei, ela não tem sido respeitada pela maioria das empresas. ${ }^{29}$ Nesse sentido, a formação da comissão citada acima significou o reconhecimento do sindicato como interlocutor e a criação de uma nova instância de negociação, o que representa um ganho para os trabalhadores. Por exemplo, o sindicato pode participar da escolha dos indicadores para a aferição dos resultados, definindo suas vantagens e desvantagens para os trabalhadores. ${ }^{30}$

Em relação às condições de trabalho, os trabalhadores do setor obtiveram redução da jornada de trabalho (36 horas semanais para telefonistas e para os que utilizam audiofones e terminais de vídeo e 40 horas semanais para os demais empregados), sem redução de salário, ganho que foi mantido após a privatização.

Quanto ao pagamento de horas extras, houve, após a privatização, redução de $50 \%$ no valor pago às horas subseqüentes às duas primeiras; não há referências a restrições ou proibição de horas extras. Esse resultado contraria as reivindicações sindicais, que propõem o aumento do per- centual da remuneração de horas extras como forma de restringi-las.

Verifica-se a ausência de cláusula sobre o chamado "banco de horas", o que pode ser considerado uma vitória do sindicato, contrário a esse procedimento por julgá-lo danoso aos interesses dos trabalhadores (compensação de horas extras por folgas imprevistas, jornadas prolongadas, rebaixamento da remuneração), mas que tem sido insistentemente defendido pelo empresariado como forma de flexibilizar o tempo de trabalho para melhor enfrentar as oscilações do mercado. No entanto, a rejeição do sindicato não impede negociações individuais entre empresa e trabalhadores.

No que se refere a demissões, antes mesmo da privatização (acordo coletivo de 1995-1996), o compromisso de a empresa não dispensar empregados atingidos pela introdução de novas tecnologias foi extinto, mas foi mantida a cláusula de comprometimento da empresa no sentido de realizar programas de recapacitação e de realocação desses empregados. Nos dois últimos acordos, entretanto, não há referência à realocação, mas somente à capacitação e ao programa de desenvolvimento profissional. As cláusulas relativas à divulgação prévia a todos empregados dos procedimentos sobre avaliação e critérios de promoção e ao compromisso de a empresa reduzir gradativamente a subcontratação/terceirização foram extintas a partir de 1998. Nesse aspecto, pode-se observar uma sensível perda do sindicato em relação à sua preocupação com a questão do aumento da terceirização, visto que, após a privatização, houve um crescimento significativo da subcontratação.

Quanto às questões relativas à saúde e à segurança no trabalbo, não houve alterações no que já tinha sido assegurado aos trabalhadores. Contudo, não existe qualquer regulamentação relativa ao ritmo e/ou à intensidade de trabalho, um aspecto crucial, dada a intensificação do ritmo de trabalho. Essa omissão significa, evidentemente, uma perda para os trabalhadores.

A propósito das relações sindicais, houve restrição na liberação de dirigentes e, nos dois últimos acordos, há uma ressalva de que o número de dirigentes liberados poderá ser reduzido, o 
Quadro 2

Acordos Coletivos de Trabalho: CRT, Telemar/MG, Telemar/RJ e Empreiteiras

\begin{tabular}{|c|c|c|c|c|c|c|c|c|}
\hline \multirow{2}{*}{$\begin{array}{c}\text { Empresas- } \\
\text { Período/Itens }\end{array}$} & \multicolumn{2}{|c|}{ CRT } & \multicolumn{2}{|c|}{ TELEMAR/MG } & \multicolumn{2}{|c|}{ TELEMAR/RJ } & \multicolumn{2}{|c|}{ EMPREITEIRAS } \\
\hline & $1999-2000$ & 2001-2002 & 2000 & 2001 & 2000 & 2001 & $2000^{*}$ & $2001^{*}$ \\
\hline \multicolumn{9}{|l|}{ REMUNERAÇÃO } \\
\hline $\begin{array}{l}\text { Reajuste } \\
\text { Salarial }\end{array}$ & $\begin{array}{l}\text { Abono: } \\
\text { R\$ 917 + 26\% } \\
\text { salário }\end{array}$ & $\begin{array}{l}\text { Até } \mathrm{R} \$ 6.000, \\
6 \% ; \text { Acima } \\
\mathrm{R} \$ 6.000,4 \% \\
\text { incorpor. ao } \\
\text { salário; } \mathrm{R} \$ \\
825 \text { a todos }\end{array}$ & $\begin{array}{l}\text { Até } \mathrm{R} \$ 1700 \text {, } \\
2 \% \text { incorpo- } \\
\text { rado ao salá- } \\
\text { rio; acima } \\
\mathrm{R} \$ 1.700 \text { sem } \\
\text { reajuste }\end{array}$ & $\begin{array}{l}\text { Até } \mathrm{R} \$ 1.500, \\
3 \% ; \text { acima } \\
\mathrm{R} \$ 1.500, \text { sem- } \\
\text { reajuste; abo- } \\
\text { no } \mathrm{R} \$ 470 \mathrm{a} \\
\text { todos }\end{array}$ & $\begin{array}{l}\text { Até } \mathrm{R} \$ 1.700, \\
2 \% \text { incorpor. } \\
\text { salário; acima } \\
\mathrm{R} \$ 1.700 \text { sem } \\
\text { reajuste }\end{array}$ & $\begin{array}{l}\text { Até } \mathrm{R} \$ 1.500 \\
3 \% \text {; acima } \mathrm{R} \$ \\
1.500 \text { sem } \\
\text { reajuste }\end{array}$ & $\begin{array}{l}\text { Fixação piso } \\
\text { salarial }\end{array}$ & $\begin{array}{l}\text { Reajuste do } \\
\text { piso salarial } \\
\text { para todos os } \\
\text { cargos, em re- } \\
\text { lação ao acor- } \\
\text { do anterior }\end{array}$ \\
\hline $\begin{array}{l}\text { Participação } \\
\text { nos lucros } \\
\text { e/ou resulta- } \\
\text { dos (PLR) }\end{array}$ & $\begin{array}{l}80 \% \text { salário e } \\
20 \% \text { fixo. An- } \\
\text { tecipação } \\
\text { R } \$ 1.200 \text { cfe. } \\
\text { metas até } \\
\text { abril } 2000\end{array}$ & $\begin{array}{l}80 \% \text { sal. e } \\
\text { 20\% fixo. Lim. } \\
\text { 1,2 sal. Metas } \\
\text { até ago/01: } \\
\text { 1,8 salário a } \\
\text { todos }\end{array}$ & $\begin{array}{l}\text { Há algumas } \\
\text { regras sem } \\
\text { acordo com } \\
\text { o sindicato }\end{array}$ & $\begin{array}{l}\text { Promessa de } \\
\text { acordo com } \\
\text { participação } \\
\text { do sindicato } \\
\text { em } 2002\end{array}$ & & & $\begin{array}{l}\text { Caso empre- } \\
\text { sa venha im- } \\
\text { plantá-la, de- } \\
\text { verá } \\
\text { comunicar } \\
\text { SINTTEL-RS }\end{array}$ & $\begin{array}{l}\text { O sindicato e } \\
\text { a empresa } \\
\text { celebrarão } \\
\text { oportuna- } \\
\text { mente acordo } \\
\text { de PPR }\end{array}$ \\
\hline $\begin{array}{l}\text { Gratificação } \\
\text { de férias }\end{array}$ & CLT & CLT & CLT & CLT & & CLT & & \\
\hline \multicolumn{9}{|l|}{ EMPREGO } \\
\hline $\begin{array}{l}\text { Jornada de } \\
\text { trabalho }\end{array}$ & $\begin{array}{l}36 \text { hs telefon. } \\
\text { e empr. c/ au- } \\
\text { dio e vídeo; } \\
40 \text { hs demais } \\
\text { s/ red sal. }\end{array}$ & Mantida & Mantida & Mantida & $\begin{array}{l}\text { Mantida } \\
\text { Poderá ser } \\
\text { exigida } 44 \text { hs } \\
\text { semanais }\end{array}$ & Mantida & $\begin{array}{l}44 \text { horas } \\
\text { semanais }\end{array}$ & $\begin{array}{l}44 \text { horas } \\
\text { semanais }\end{array}$ \\
\hline Horas extras & $\begin{array}{l}\text { Adic. } 50 \% \\
\text { cfe. CLT }\end{array}$ & $\begin{array}{l}\text { Adic. } 50 \% \\
\text { cfe. CLT }\end{array}$ & $\begin{array}{l}\text { Adic. } 50 \% \\
\text { cfe. CLT }\end{array}$ & $\begin{array}{l}\text { Adic. 50\% } \\
\text { cfe. CLT }\end{array}$ & $\begin{array}{l}\text { Adicional } \\
50 \% \text {, cfe. CLT }\end{array}$ & $\begin{array}{l}\text { Adic. } 50 \% \\
\text { cfe. CLT }\end{array}$ & $\begin{array}{l}\text { Adicional } \\
50 \% \text {, cfe. CLT }\end{array}$ & $\begin{array}{l}\text { Adicional } \\
50 \% \text {, cfe. CLT }\end{array}$ \\
\hline $\begin{array}{l}\text { Banco de } \\
\text { Horas }\end{array}$ & & & & $\begin{array}{l}\text { Em } \\
\text { negociação }\end{array}$ & CLT & CLT & $\begin{array}{l}\text { Negociação } \\
\text { posterior com } \\
\text { sindicato }\end{array}$ & \\
\hline $\begin{array}{l}\text { NT/Programa } \\
\text { de capacacita- } \\
\text { ção, realoca- } \\
\text { ção e desen- } \\
\text { volvimento } \\
\text { profissional }\end{array}$ & $\begin{array}{l}\text { Programa de } \\
\text { capacitação e } \\
\text { desenvolvi- } \\
\text { mento profis- } \\
\text { sional empreg. } \\
\text { atingidos NT/ } \\
\text { automação }\end{array}$ & $\begin{array}{l}\text { Programa de } \\
\text { capacitação e } \\
\text { desenvolvi- } \\
\text { mento profis- } \\
\text { sional empreg. } \\
\text { atingidos NT/ } \\
\text { automação }\end{array}$ & Extinta & Extinta & Extinta & Extinta & & \\
\hline
\end{tabular}

RELACÕES SINDICAIS

\begin{tabular}{l|l|l|l|l|l|l|l|l}
\hline $\begin{array}{l}\text { Liberação de } \\
\text { dirigentes }\end{array}$ & $\begin{array}{l}\text { Até 12 em- } \\
\text { pregados } \\
\text { com remune- } \\
\text { ração }\end{array}$ & $\begin{array}{l}\text { Até 12 em- } \\
\text { pregados } \\
\text { com remune- } \\
\text { ração }\end{array}$ & $\begin{array}{l}\text { Até 6 empre- } \\
\text { gados com } \\
\text { remuneração }\end{array}$ & $\begin{array}{l}\text { Até 6 empre- } \\
\text { gados com } \\
\text { remuneração }\end{array}$ & $\begin{array}{l}\text { Até 7 empre- } \\
\text { gados com } \\
\text { remuneração } \\
\text { e 4 sem re- } \\
\text { muneração }\end{array}$ & $\begin{array}{l}\text { Até } 7 \text { empre- } \\
\text { gados com } \\
\text { remuneração } \\
\text { e 4 sem re- } \\
\text { muneração }\end{array}$ & $\begin{array}{l}\text { Até } 5 \text { empre- } \\
\text { gados com } \\
\text { remuneração }\end{array}$ & $\begin{array}{l}\text { Até 5 empre- } \\
\text { gados com } \\
\text { remuneração }\end{array}$ \\
\hline Comissões & $\begin{array}{l}\text { Sinttel e CRT } \\
\text { c/ obj. conci- } \\
\text { liar confl. co- } \\
\text { let. e/ou in- } \\
\text { div. de trab. }\end{array}$ & $\begin{array}{l}\text { Sinttel e CRT } \\
\text { c/ objet. Con- } \\
\text { ciliar confl. } \\
\text { Coletivo e/ou } \\
\text { indiv. de tra- } \\
\text { balho }\end{array}$ & & & & & & \\
\hline
\end{tabular}

*Em 2000, o acordo incluiu três empreiteiras.

**Em 2001, os acordos foram firmados por cada empreiteira separadamente.

Fonte: Elaboração a partir dos Acordos Coletivos de Trabalho firmados entre o SINTTEL, operadoras e empreiteiras (1999-2001). 
que já acontece em outros sindicatos do setor (ver Quadro 2). Essa redução afeta o desempenho dos sindicatos tendo em vista a maior necessidade de pessoal ante a atual diversidade de situações e as dificuldades para a remuneração de pessoal.

Ao se examinar comparativamente os últimos acordos firmados entre os três sindicatos selecionados e as respectivas operadoras, observam-se tendências convergentes e divergências, conforme mostra o Quadro 2.

No que se refere a convergências, pode-se observar o desaparecimento de concessão de reajustes lineares (os reajustes passaram a ser escalonados por faixas salariais); também foram extintas as cláusulas relativas a uma série de benefícios, como, por exemplo, reajustes conforme a variação do índice oficial de inflação, anuênios, produtividade, gratificação de férias e valor das horas extras. Em todos os casos analisados, a produtividade passou a ser negociada no âmbito da PLR, sem incorporação aos salários, embora haja distinções relativas a formas, critérios e valores negociados nos diferentes acordos. No caso da Telemar/MG, não foi firmado um acordo, apenas regras estabelecidas entre a empresa e uma comissão de trabalhadores, sem a presença do sindicato. Entretanto, no último acordo, há uma cláusula que se compromete a garantir a presença do sindicato em futuras negociações da PLR. Observa-se, ainda, a ausência de cláusulas referentes à limitação da subcontratação, um dos aspectos mais caros aos sindicatos de telecomunicações no momento. Da mesma forma, foram excluídas, nos acordos analisados, as cláusulas que garantiam aos trabalhadores o acesso a informações sobre critérios de avaliação, desempenho e promoções. Além disso, foram mantidas as cláusulas relativas à jornada de trabalho, garantindo a redução da jornada sem redução salarial. No entanto, nos acordos firmados pelo sindicato e a Telemar/RJ, há um adendo que indica a possibilidade de aumento da jornada de trabalho para 44 horas semanais, o que representa um retrocesso, já que a tendência mundial é de redução da jornada. Finalmente, houve redução do número de dirigentes liberados com remuneração para atividades sindicais. A CRT foi a mais generosa, embora, te- nha incluído um adendo advertindo sobre a possibilidade de redução de liberações no futuro.

Observam-se divergências em relação à remuneração. Diferentemente da CRT (até o acordo 2000-2001), a Telemar, nos dois Estados examinados (Minas Gerais e Rio de Janeiro), concedeu reajustes incorporáveis aos salários, ainda que escalonados (2\% para empregados com salários de até R \$ 1.700, em 2000, e 3\% para salários até R\$1.500, em 2001, mantendo sem reajuste empregados com salários acima desses valores). Os sindicatos são decididamente contrários a esse tipo de diferenciação, pois ela rompe com os princípios de homogeneidade e solidariedade sobre os quais eles baseiam suas estratégias e garantem a legitimidade. Além disso, a diferenciação salarial estabelece mais um fator de variabilidade com o qual os sindicatos têm dificuldades em lidar. No caso em exame, a diferenciação pode resultar em redução da desigualdade salarial, embora possa contribuir para afastar do sindicato o segmento não contemplado com reajuste. Em contrapartida, a vantagem de ser incorporável ao salário fica relativizada, uma vez que o reajuste é inferior à variação do índice anual de inflação. Reiterando, a CRT, no último acordo firmado, aproximou-se das demais operadoras ao conceder reajuste por faixas salariais, incorporáveis ao salário. Contudo, assumiu uma posição diferenciada ao conceder reajustes a todos os empregados, com valores percentuais e faixas salariais mais elevados, o que expressa a situação particular da empresa na conjuntura atual, em razão, sobretudo, da premência no cumprimento de metas e das pressões do mercado de trabalho na região.

Outra divergência diz respeito aos programas de capacitação e de desenvolvimento profissional para empregados atingidos por novas tecnologias e automação. Nos casos analisados, apenas houve referência a esse respeito no acordo da Sinttel/RS-CRT, em que a empresa manteve os programas de capacitação e de desenvolvimento profissional. A manutenção dessa cláusula (embora mais restrita do que nos acordos pré-privatização) significa uma vitória para o sindicato, já que há pouca disposição do empresariado brasileiro em investir em planos de qualificação ou 
mesmo negociar esse tipo de acordo. ${ }^{31}$ Ademais, houve também divergência quanto à constituição de comissão paritária (empresa e sindicato) com o objetivo de conciliar conflitos coletivos e/ou individuais fora do âmbito da Justiça do Trabalho. Por fim, há diferenciação quanto à negociação referente à implementação do chamado "banco de horas" acordado entre Sinttel/RJ-Telemar/RJ, o qual representa, conforme já referido, a flexibilização da jornada de trabalho e o não pagamento monetário de horas extras.

Um aspecto relevante a ser destacado diz respeito às novas estratégias sindicais e, em particular, ao acordo firmado pelo Sinttel/RS e três empreiteiras (2000).32 Embora tenha limitado-se a reproduzir aspectos básicos previstos pela legislação (registro dos contratos de trabalho, jornada semanal de 44 horas, pagamento de horas extras, cumprimento de normas de segurança, adicional de periculosidade e insalubridade, homologação de rescisões no sindicato para empregados com mais de um ano na empresa, ressarcimento de despesas realizadas pelo empregado para a realização do trabalho, como utilização de veículo e telefones próprios), o acordo foi relevante ao garantir direitos trabalhistas básicos, em geral, desrespeitados. Obteve, assim, conquistas como definição de pisos salariais de acordo com cargos e funções; ressarcimento ao empregado de despesas realizadas com a utilização de veículos próprios para a realização de trabalho da empresa; obrigação da empresa de liberar os empregados para tratamento médico e/ou odontológico sem prejuízo de salário; estabilidade no emprego provisória após licença gestante de trinta dias; estabilidade para o representante sindical eleito e liberação remunerada de empregados eleitos ou indicados pelo sindicato, além de outros benefícios não monetários, como bônus refeição, entre outros.

Talvez mais significativo do que os ganhos imediatos seja a mudança de atitude do sindicato de telecomunicações, que passou a se preocupar, pela primeira vez, em ampliar sua base, incluindo, empresas prestadoras de serviço, onde, em geral, os trabalhadores se encontravam desprotegidos e excluídos do sindicato.

\section{Conclusão}

Voltando à questão inicial sobre qual seria a situação atual dos sindicatos diante dos novos desafios - crise ou novas estratégias? -, talvez seja possível afirmar que ambas as hipóteses estejam presentes e que a constatação de uma ou de outra depende da perspectiva do analista. A idéia de crise apresenta-se para os que entendem os sindicatos como um movimento classista, que atua na esfera própria do mundo fordista, na perspectiva do conflito. Esse tipo de sindicalismo está realmente em crise. A idéia de "novas estratégias" afirma-se para os que percebem a realidade em movimento, onde os atores se reorientam, criando novos campos de conflito e de negociação. Nessa perspectiva, enfoca-se a concepção de transição, em que a realidade não se encontra estagnada, nem os atores congelados, mas reagindo a novas situações, propondo novas agendas, errando, mas também abrindo novas oportunidades. Tal transição deverá ser longa e gradativa.

Um aspecto importante resultante da desregulamentação/privatização foi a mudança de uma realidade que durante décadas se caracterizou pela homogeneidade para uma outra marcada por grande heterogeneidade. Os sindicatos de telecomunicações, influentes mundialmente em grande medida por causa das características do setor - empresas monopólicas operando como concessionárias de serviço de utilidade pública -, viram-se ameaçados sob condições político-econômicas adversas e, ao mesmo tempo, despreparados para atuar em situação de grande variabilidade. Perplexos diante de tais desafios, eles procuram enfrentar a nova situação, ainda que de forma lenta e defensiva.

No entanto, a diversidade nas práticas de trabalho, no mercado de trabalho, entre os trabalhadores e no local de trabalho, de maneira geral, veio para ficar. Os próprios sindicatos terão de basear seus princípios no conceito de diversidade. Assim, será necessário que eles considerem suas ações num contínuo que vai da cooperação ao antagonismo, utilizando-se em graus distintos um e/ou outro, de acordo com as circunstâncias (Katz et al., 2002, p. 2). 
Outra dificuldade decorre do tipo de estratégia gerencial a ser adotada. Quanto mais as empresas se apoiarem no rebaixamento do custo da mão-de-obra como estratégia de competitividade, maior serão as dificuldades de os sindicatos atingirem os objetivos de melhoria das condições de trabalho. Os resultados positivos alcançados na Alemanha e em algumas operadoras regionais nos Estados Unidos resultaram de um ambiente de regulação favorável às empresas, refletindo-se nas relações entre estas e os sindicatos.

Comparando-se as experiências do Brasil e dos Estados Unidos quanto à ação sindical no setor de telecomunicações, observa-se um ponto de partida comum: a empresa monopólica oferecendo serviços de utilidade pública sob um único sistema de emprego, além das relações sindicato-empresa estarem próximas do paternalismo. O setor tornouse competitivo, globalizado, diversificado e heterogêneo, num ambiente pouco amistoso aos sindicatos. As diferenças, principalmente em termos de grau, poderiam talvez ser atribuídas a fatores como a natureza mais complexa e dinâmica do setor nos Estados Unidos antes e depois da reestruturação, bem como ao tempo decorrido desde a quebra do monopólio - cerca de vinte anos, nos Estados Unidos; cinco anos, no Brasil. Nesses vinte anos de reestruturação marcados por grandes mudanças $\mathrm{e}$ dificuldades, o CWA tem sido capaz de criar novas estratégias para garantir sua sobrevivência, ainda que contabilizando perdas, sobretudo em termos de queda expressiva do número de filiados.

O CWA abandonou a perspectiva simplista baseada no dualismo cooperação versus antagonismo no que se refere as relações sindicato-empresa e passou a agir numa esfera que, dependendo das circunstâncias, comporta tanto estratégias de cooperação como de antagonismo. Quando bem exploradas, essas estratégias possibilitam a realização de outros objetivos, o que contribui para elevar a eficácia da ação sindical e, em conseqüência, sua legitimidade.

No Brasil, a ação sindical nas telecomunicações, que no início do processo se manteve próxima à perspectiva dualista, parece agora se encaminhar no sentido de substituir a postura de confronto pela de negociação, cujo exemplo mais notório foi a negociação da PLR. Após grande resistência por parte dos sindicatos, ela vem sendo implementada no setor.

Outra estratégia bem-sucedida nos Estados Unidos foi a fusão de sindicatos, ou seja, o sindicato de telecomunicações passou a ser sindicato do setor de informação. Com isso, o CWA foi capaz de expandir o número de trabalhadores sindicalizados e de penetrar nas novas áreas emergentes, passando a atingir profissionais mais qualificados, como jornalistas e especialistas em softwares, entre outros.

Essa estratégia ainda é incipiente no Brasil. Podem ser observados alguns esforços em torno de uma possível fusão entre as federações de telecomunicações e de informática, tendo em vista constituir a Federação de Telemática, que uniria os sindicatos de processamento de dados, TV a cabo e telecomunicações. Contudo, em virtude de disputas pelo poder e de diferenças político-ideológicas, essa iniciativa tem encontrado dificuldades para ser implementada no país. A construção de uma instituição capaz de atuar em um nível mais abrangente unindo setores-chave da economia, como os de informática e telecomunicações, representaria um ganho notável para os sindicatos.

Estratégia ousada em desenvolvimento nos Estados Unidos, mas com grande dificuldade de se impor, refere-se à atuação em nível internacional, por meio da tentativa de buscar alianças e joint ventures com sindicatos fora do país. Exemplo disso foram as experiências de campanhas conjuntas com sindicatos canadenses e mexicanos.

Essa idéia também começa a ser considerada no Brasil. Em 2001, realizou-se uma reunião dos funcionários das filiais da empresa Telefónica de Espanha procedentes de dez países, incluindo o Brasil. O objetivo era criar um comitê para definir planos de ação conjunta. Esse tipo de iniciativa tem-se difundido em outros ramos de atividades: funcionários das filiais de sete países do Banco Santander, também sediado na Espanha, realizaram o segundo encontro naquele país de sua Coordenação Sindical. Outra reunião ocorreu no Chile com funcionários do Banco Bilbao Viscaya, também espanhol, com o objetivo de criar uma Coordenação Sindical. Trabalhadores da General Motors, da Fiat do Brasil e da Ford do Brasil tam- 
bém procuram se organizar, reunindo trabalhadores de diferentes países latino-americanos, para desenvolver estratégias conjuntas ( O Estado de São Paulo, 7/8/2001).

Talvez esse seja o grande desafio para um novo patamar de lutas sindicais no século XXI. Embora tardiamente, parece se concretizar a velha palavra de ordem do marxismo: "Trabalhadores do mundo, uni-vos".

Por outro lado, a necessidade de ampliar a base de representação força os sindicatos a aproximarem-se de segmentos de trabalhadores subcontratados - caso da Wash Tech nos Estados Unidos e de trabalhadores em empresas subcontratadas no Brasil. Esse tipo de iniciativa garante a esses trabalhadores benefícios básicos de que careciam até então, o que certamente contribuirá para reduzir a lacuna existente entre trabalhadores de empresas core e de empresas periféricas ou trabalhadores contingentes ou atípicos. Nesse sentido, o sindicato deve atuar não simplesmente como coadjuvante, mas sobretudo como agente transformador.

No Brasil, como nos Estados Unidos, observase a marca da diversidade que caracterizou o setor após a privatização, especialmente no que se refere ao número de novas empresas que passaram a atuar sob controle estrangeiro, apresentando, sob vários aspectos, diferenças significativas entre si. Além disso, o setor encontra-se em fase de construção, e é previsto que venha a se transformar cada vez mais com aquisições, fusões e alianças, criando novas empresas, com novas identidades. Também no Brasil, encontramos a divisão da empresa conforme segmentos de mercado, além de externalização de atividades, inclusive de atividades-fim. Diante de tão significativa reestruturação, acrescida de uma conjuntura desfavorável aos sindicatos, não é de se admirar que eles estejam enfraquecidos. Apesar dos desafios, os sindicatos, ainda que de maneira defensiva, tentam resistir apoiando-se em novas estratégias.

A reestruturação das empresas e a globalização impõem mudanças aos sindicatos marcados por um tipo de ação baseada no nacionalismo, no coletivismo, na homogeneidade e na rigidez. Tornou-se necessário que sua ação volte-se tanto à esfera global como à local, e paute-se pelo plura- lismo, pela diferenciação e complexidade, pela flexibilidade e contingência. A realidade atual exige novos conceitos políticos e sociais e, sobretudo, dramáticas transformações culturais. Ganhará quem for capaz de reverter situações contingentes e flexíveis em seu favor. Será preciso formular políticas alternativas de forma criativa. Para isso, é fundamental um grande investimento em capacitação das lideranças sindicais no sentido de superar certos dogmas que se mostram, hoje, sem eficácia.

\section{NOTAS}

1 O Sistema Bell era monopólio privado e Sistema Telebrás, estatal; após a reestruturação nos Estados Unidos, o setor expandiu-se de forma notável, transformando-se em setor de informação, enquanto no Brasil, a expansão mantém-se sobretudo no nível da telefonia. Nos Estados Unidos, o processo de quebra do monopólio desenvolve-se há pelo menos vinte anos, e, no Brasil, é ainda recente e restrito.

2 Para uma descrição mais detalhada desse processo, ver Larangeira, 1998.

3 Apenas 2\% da receita do mercado mundial provém de operadoras não privatizadas; o restante, 13\% provém de companhias privadas que coexistem com as concessionárias (estatais) (ITU, 2002, p. 4).

4 No Brasil, verifica-se também uma mudança expressiva na estrutura do setor de telecomunicações: em 2000, os serviços de telefonia fixa foram responsáveis por $43,7 \%$ da receita gerada no setor; os de telefonia celular por $32,8 \%$ da receita, enquanto, transmissão de dados, internet e interconexão responderam por 23,5\% (PAS/IBGE, 2000).

5 A nova realidade do setor seria responsável pela chamada "desigualdade digital", referência às diferentes oportunidades de acesso à internet e a outras formas de comunicação eletrônica, que, em comparação como o telefone, têm uma distribuição bem mais desigual.

6 Nesse contexto, a tradicional medida de avaliação do nível de comunicação de uma população, número de linhas telefônicas por 100 habitantes, deixa de expressar a realidade dessa população em relação aos serviços de comunicação. 
7 O número de usuários inscritos nos Estados Unidos em maio de 2003 era de 145.737 .905 .

8 Dados revisados em maio de 2000.

9 Para detalhes sobre esse processo, ver Keefe e Boroff (1994).

10 As operadoras regionais, baby Bells (antes da desregulamentação somavam 22, reorganizadas após em sete e, nos anos de 1990, foram reduzidas a quatro), reduziram o número de empregados em $28 \%$, entre 1984-1992. (Keefe \& Batt, 1997:55)

11 A IBM é responsável pela manutenção dos software, o que era realizado por empregados sindicalizados da AT\&T; 70\% do serviço de atendimento a clientes na AT\&T é desempenhado por empresas subcontratadas; os serviços de recursos humanos e pagamento deverão também ser subcontratados.

12 Os dados relativos aos Estados Unidos correspondem ao ano de 2002, o que não ocorre para os demais países.

13 Segmentação é uma estratégia largamente usada. Na Alemanha, a Voice Stream Wireless, uma unidade da DeutscheTelekom, aplica o princípio da segmentação aos clientes: o sistema de computador direciona as chamadas dos clientes de acordo com o valor de suas contas mensais (Wall Street Journal, 17/4/2002). A segmentação da força de trabalho em função do mercado é uma prática usual nos call centers, no Brasil.

14 Em relação ao Workplace of the Future, "executivos nas subsidiárias não estão comprometidos a trabalhar com as lideranças sindicais, já que estão sob forte pressão para focar em $\mathrm{P} \& \mathrm{D}$, tendo em vista o desenvolvimento de novos produtos. Em conseqüência, freqüentemente, tomam decisões de forma apressada sem consultar os líderes sindicais nacionais" (Osterman et al. 2001, pp. 72-73).

15 "Os sindicatos historicamente apoiaram as companhias do sistema Bell diante das comissões reguladoras; atualmente eles o fazem sob a condição de reciprocidade, ou seja, desde que as companhias os apóiem em seus objetivos de organização e de negociação coletiva" (Katz et al., 2002, p. 1). O CWA está interessado no crescimento das RBOCs (baby Bells), já que conta com um número significativo de filiados nessas companhias (Batt et al., 1999).
16 Empregados de serviços de atendimento a clientes é um grupo em crescimento e constitui-se em extensão da base tradicional de empregados em companhias telefônicas.

17 Para um detalhado estudo desse caso, ver Van Jaarsveld (2000).

18 Embora "a correção salarial previamente negociada tenha sido ou reduzida, ou suspensa ou eliminada em todas as companhias no decorrer da década.", houve um crescimento médio dos aumentos salariais de 2,2\%, em 1986, para 3,7\%, em 2000. Na AT\&T, o crescimento da média de aumento salarial foi significativo, passando de 2,0\%, em 1986, para 6,12\%, em 2002-2003 (Katz et al. 2002; entrevista com liderança sindical do CWA em março, 2002).

19 É interessante notar que o mesmo não ocorre na Alemanha Oriental, onde os sindicatos têm tido pouco êxito em sua institucionalização. Há uma menor integração com os conselhos de fábrica (Katz e Darbishire, 2000, pp. 210-221).

20 A modernização do sistema de telecomunicações requer investimentos de monta. A magnitude desses investimentos seria um dos fatores responsáveis pela globalização do setor. Gastos da ordem de US\$ 1 bilhão para o desenvolvimento de sistemas digitais exigiria uma participação de cerca de $8 \%$ do mercado mundial, apenas para recuperar os custos dos investimentos (Walter, 1998, pp. 18-19). A quebra do monopólio do Sistema Bell nos Estados Unidos resultou de um movimento que congregou algumas operadoras lideradas pela $\mathrm{MCI}$, a indústria de computadores liderada pela IBM, usuários corporativos como grandes multinacionais, os serviços financeiros e as companhias de aviação, interessadas em baixar os preços dos serviços e eliminar o "subsídio cruzado". Mais de $70 \%$ dos consumidores norte-americanos e a própria administração Reagan opunham-se à quebra do monopólio (Batt, 1995, pp. 88, 90-91).

21 Com a crise financeira "os recursos do FNT foram progressivamente destinados a financiar outras despesas do governo, deixando de ser repassados ao sistema Telebrás. Em 1986, o FNT foi extinto e substituído pelo Imposto sobre Serviços de Comunicação (ISSC). Posteriormente, em 1989, o ISSC teve sua alíquota reduzida de $27 \%$ para $5 \%$ e foi repassado aos municípios, conforme determinação da Constituição de 1988" (Costa, s. d, p. 12). 
22 Compare-se a teledensidade no Brasil, em meados da década de 1990, com a dos Estados Unidos, em 1960, em que 95\% da população possuía serviços telefônicos (Batt, 1995, p. 93).

23 Nos Estados Unidos, por exemplo, "somente 6,7 dos consumidores utilizam-se dos serviços de outras companhias que não as tradicionais operadoras locais, as baby Bells". (CWA, 2002, p. 10).

24 Esse crescimento deve-se em grande parte à implantação do sistema pré-pago, o que também se verificou em países como Itália, França e Grã Bretanha. As estimativas são de que, mundialmente, a modalidade pré-pago supere a pós-pago. Além disso, o preço da habilitação, que era cerca de $\mathrm{R} \$ 500,00$, em 1995, chegou a cair praticamente a zero, em 1999.

25 Adquirida inicialmente pela Telefónica de España que, após comprar a Telesp, foi obrigada a se desfazer da CRT, então adquirida pela Brasil Telecom Participações S. A.

26 Em 1994, o governo extinguiu a política salarial e instituiu a PLR por meio de medida provisória, o que possibilitou vincular a remuneração aos resultados obtidos pela empresa. A parte variável da remuneração era isenta de encargos sociais, com possibilidade de dedução no imposto de renda. A negociação da PLR levou à descentralização da negociação.

27 Levantamento realizado pelo Dieese indica que no período de 1996-1997 se verificou um aumento expressivo no número de acordos de PLR (Dieese, 2000).

28 Segundo levantamento realizado pelo Dieese, a modalidade PR foi a mais usual $(54,3 \%$ do total dos acordos analisados no período de 1996-1999). No acordo entre CRT e Sinttel-RS, os indicadores negociados foram: tempo de até oito horas para reparo de telefones de uso público e não residenciais, e de até 24 horas para residenciais; taxa de chamadas completadas; número de reclamações em cada cem contas emitidas; absenteísmo; receita operacional líquida e instalações de telefonia básica; exames médicos periódicos.

29 Estudos mostram que aumentou o número de acordos sobre PLR no país, sendo que a maioria foi firmada sem a participação direta dos sindicatos (Martins e Rodrigues, 1999, pp. 177-178).
30 Por exemplo, indicadores como receita operacional ou número de clientes não são considerados favoráveis aos trabalhadores, pois dependem da situação de mercado e podem sofrer redução em razão da concorrência; outro indicador considerado desfavorável é absenteísmo por doença, já que pode levar ao ocultamento da doença. Outros são preferidos por serem diretamente ligados aos trabalhadores, de fácil acesso para aferição e de difícil manipulação para a empresa, como "chamadas completadas", "número de telefones de uso público em serviço", "qualidade de serviço", "qualidade da rede" (ver lista de indicadores no site da Anatel).

31 Para ilustrar as perdas dos sindicatos e dos trabalhadores nessa área, cabe registrar o caso da antiga estatal regional Telemig, hoje, Telemar/MG: a empresa foi pioneira no Brasil ao introduzir uma cláusula sobre novas tecnologias (1985), prevendo a readaptação e o reaproveitamento dos trabalhadores quando da introdução de novas tecnologias, o que foi reproduzido por outros sindicatos, inclusive pelo Sinttel/RS. A referida cláusula continuou sendo renovada e até ampliada para assegurar o direito a treinamento, realocação e manutenção de emprego aos empregados atingidos pela introdução de novas tecnologias. O Sintel/MG possuía uma diretoria de tecnologia voltada para o desenvolvimento de ações nessa área. Após a privatização, em 1998, o sindicato encontrou enormes dificuldades em negociar com a empresa essa cláusula nos acordos coletivos entre Sintel/MG e Telemar/MG (Cotanda, 2001, pp. 181-197).

32 O acordo de 2001 foi negociado separadamente, com cada empresa.

\section{BIBLIOGRAFIA}

ALBUQUERQUE, Antônio; DANTAS, Marcos \& COSTA, Maria Conceição. (1999), "Telecomunicações: um ano de sistema privado no Brasil". Texto apresentado no Congreso de ALAS, Concepción, Chile, out., mimeo.

BATT, Rosemary. (1993), Work reorganization and labor relations in telecommunications services: a case study of BellSouth Corporation. MIT IPC Working Paper, Cambridge, Ma, ago. 
. (1995), Performance and welfare effects of working restructuring: evidence from telecommunications services. $\mathrm{PhD}$ dissertation, Sloan School, MIT, Cambridge, Ma.

(2001), "Explaining wage inequality in telecommunications services: customer segmentation, human resource practices, and union decline". Industrial and Labor Relations Review, 54 (2A): 425-449.

BATT, Rosemary \& KEEFE, Jeffrey. (1999), "Human resource and employment practices in telecommunications services, 1980-1998", in Peter Capelli (ed.), Employment practices and business strategy, Nova York/Oxford, Oxford University Press.

BATT, Rosemary; KATZ, Harry \& KEEFE, Jeffrey. (1999), "The strategic initiatives of the CWA: organizations, politics and collective bargaining". Task Force WP\#15, Cambridge, MIT, Sloan School.

BATT, Rosemary \& STRAUSSER Michael. (1998), "Labor markets outcomes of deregulations in telecommunications services", in IRRA, Paper and proceedings of the annual meetings of the IRRA, Madison, Mi, IRRA, pp. 126-134.

BATT, Rosemary \& DARBISHIRE, Owen. (1997), "Institutional determinants of deregulation and restrutucturing in telecommunications: Britain, Germany and the United States compared". Cambridge Political Economy Society.

CARVALHO NETO, Antonio Moreira de. (1998), "La desreglamentación de las telecomunicaciones en Brasil", in Jorge Walter e Cecilia Senén González, La privatizaciónde las telecomunicaciones en la América Latina, Buenos Aires, Eudeba.

COHEN, Larry \& EARLY, Steve. (1999), "Defending workers' rights in the global economy", in Bruce Nissen (ed.), Which direction for organized labor?. Detroit, Wayne State University Press.
COSTA, Maria Conceição. (s.d.), "Reforma do Estado e privatização: a resposta para o setor de telecomunicações no Brasil. Campinas, Unicamp, mimeo.

. (1996), Mudanças institucionais e privatização na década de 90: uma comparação entre Europa e América Latina no setor de telecomunicações. Campinas, Unicamp, manuscrito.

COTANDA, Fernando. (2001), Sindicalismo e inovação tecno-organizacional: a experiência da Central Única dos Trabalhadores. Tese de doutorado apresentada no Programa de Pós-Graduação em Sociologia, Porto Alegre, UFRGS, ago.

CWA. (1999), Telecommunications merger policy. Report \& Policy Statements, fev. (www.cwa-union.org).

. (2000), SBC \& Telecommunications Industry. Washington, DC, nov. . (2002), We're fighting for our future @ ATET. Washington, DC.

DARBISHIRE, Owen. (1997), "Germany", in Harry Katz (ed.), Telecommunications: restructuring work and employment relations worldwide, Ithaca, ILR Press, Cornell University.

DIEESE. (2000), "Um balanço da participação dos trabalhadores nos lucros e resultados das empresas 1996-1999". Pesquisa DIEESE, 16, São Paulo, DIEESES, jan.

DIEESE - SUBSEÇÃO SINTTEL/RS. (2000), "Painel da telefonia fixa no Rio Grande do Sul". Porto Alegre, set., manuscrito.

FERNER, Anthony \& TERRY, Michael. (1997), "United Kingdom", in Harry Katz (ed.), Telecommunications: restructuring work and employment relations worldwide, Ithaca, ILR Press, Cornell University.

HOBDAY, Michael. (1990), Telecommunications in developing countries: the challenge from Brazil. Londres, Routledge. 
INTERNATIONAL TELECOMMUNICATION UNION (ITU). (2002), "World telecommunication development report 2002: reinventing telecoms", in ITU, Executive Summary, mar.

KATZ, Harry (ed.). (1997), Telecommunications: restructuring work and employment relations worldwide. Ithaca, ILR Press/Cornell University.

KATZ, Harry \& DARBISHIRE, Owen (eds.). (2000), Converging divergences: worldwide changes in employment systems. Ithaca, ILR Press.

KATZ, Harry; BATT, Rosemary \& KEEFE, Jeffrey. (2002), "The revitalization of the CWA integrating collective bargaining, political action, and organizing". Trabalho apresentado no IRRA Meeting, Atlanta, Ga., jan., manuscrito.

KEEFE, Jeffrey \& BATT, Rosemary. (1977), "United States", in Harry Katz (ed.), Telecommunications: restructuring work and employment relations worldwide, Ithaca, ILR Press, Cornell University.

KEEFE, Jeffrey \& BOROFF, Karen. (1994), "Telecommunications labor-management relations: one decade after AT\&T divestiture", in Paula Voos (ed.), Contemporary collective bargaining in the private industry, Madison,Wi, Industrial Relations Research Association.

KELLY, John. (1999), Rethinking industrial relations. 2 ed., Londres, Routledge.

LARANGEIRA, Sônia. (1997), "Há lugar para o sindicalismo na sociedade pós-industrial?. São Paulo em Perspectiva, 12 (1): 174-183.

. (1998), "Reestruturação no setor de telecomunicações: inovações tecnológicas, privatizaçãoe e desregulamentação: aspectos da experiência internacional". Revista Latinoamericana de Estudios del Trabajo, ano 4, 8: 159-178.
MARTINS, Heloísa de S. \& RODRIGUES, Iram J. (1999), "O sindicalismo brasileiro na segunda metade dos anos 90". Tempo Social (revista de Sociologia da USP), 11 (2): 155-182, out.

MONTHLY Labor Review. (1999), Washington DC, nov., pp. 60-74.

O ESTADO de São Paulo.(2001), 7 ago.

OIT. (2002), Reunion tripartita sobre empleo, empleabilidad e igualdad de oportunidades en los servicios de correos y telecomunicaciones. Genebra, Oficina Internacional del Trabajo, 13-17 maio.

OSTERMAN, Paul et al. (2001), Working in America: a blueprint for the new labor market. Cambridge, Ma, MIT Press.

PASTE (Perspectivas para ampliação e modernização do setor de telecomunicações), Anatel, 2000 (Internet: www.anatel.gov.br).

SANTOS, Boaventura de Souza. (s. d.), "Teses para renovação do sindicalismo em Portugal, seguidas de um apelo". Coimbra, Universidade de Coimbra.

SENNETT, Richard. (1998), The corrosion of character: the personal consequences of work in the new capitalism. Londres, W. W. Norton \& Co.

WALL Street Journal. (2002), 17 abr.

WALTER, Jorge. (1998), "Privatizaciones y relaciones laborales en la telefonia lationoamericana". Revista Latinoamericana de Estudios del Trabajo, Rio de Janeiro, Alast, ano 4, 8: 89-106.

VAN JAARSVERLD, Danielle. (2000), Nascent organizing initiatives among high-skilled contingent workers: the Microsoft-Wasbtech/CWA case. Dissertação de mestrado, Ithaca, NY, ILR, Cornell University, ago.

VEJA. (1998), 28 jul. 


\section{A REESTRUTURAÇ̃̃o dAS TELECOMUNICAÇÕES E OS SINDICATOS}

\author{
Sônia M. Guimarães Larangeira
}

Palavras-chave

Telcomunicações; Liberalização/privatização; Sindicatos; Brasil; Estados Unidos.

Este artigo examina os desafios impostos aos sindicatos de telecomunicações - cuja influência marcou mundialmente as condições de emprego e de trabalho no setor - após as mudanças ocorridas com a quebra dos monopólios e a liberação dos mercados. O estudo detém-se nos casos do Brasil e dos Estados Unidos, com referências aos casos britânico e alemão. O objetivo é responder à questão: quais as conseqüências das mudanças recentes para os sindicatos de telecomunicações, crise ou renovação? A autora apresenta dados que evidenciam as estratégias desenvolvidas pelos sindicatos ante as dificuldades presentes, concluindo que, apesar de negativamente afetados pelas mudanças, eles reagem criando novas estratégias de ação. Embora isso não lhes restitua a antiga influência, torna a crise prevista mais distante. Ademais, a autora discute as diferenças, provenientes de arranjos institucionais próprios, na forma como os sindicatos são afetados.

\section{TELECOMMUNICATIONS RE- FRAMING AND THE UNIONS}

Sônia M. Guimarães Larangeira

\section{Key words}

Telecommunications; Liberalization/ privatization; Unions; Brazil; United States

The article discusses the challenges faced by the telecommunication unions - which had an important role worldwide in influencing the industry's work and employment conditions - after market liberalization. The analysis focuses on Brazil and the United States, and brief references are made to both the German and the British cases. The objective is answering the question: which have been the consequences for telecommunication unions since the recent changes in the industry crisis or renovation? Evidence shows that unions are developing new strategies to cope with current difficulties. The conclusion is that despite being negatively affected, unions are creating new strategies that, although incapable of bringing back the past influence, have been able to keep away the so-called anticipated crisis. The different responses of unions are attributed to different institutional arrangements.

\section{LA RESTRUCTURATION DES TÉLÉCOMMUNICATIONS ET LES SYNDICATS}

\author{
Sônia M. Guimarães Larangeira
}

\section{Mots-clés}

Télécommunications; Privatisation/ libération; Syndicats; Brésil; ÉtatsUnis.

Cet article aborde les défis auxquels doivent faire face les syndicats de télécommunications - dont l'influence a profondément marqué les conditions d'emploi et de travail de ce secteur au niveau mondial - suite aux changements provoqués par la fin des monopoles et la libération des marchés. Cette étude examine les cas du Brésil et des Etats-Unis, mais se penche également sur les exemples britannique et allemand. L'objectif est de répondre à la question suivante: quelles sont, pour les syndicats de télécommunications, les conséquences de changements intervenus? Crise ou rénovation ? L'auteur présente des données qui mettent en évidence les stratégies développées par les syndicats face aux difficultés actuelles et conclut que, malgré leur influence négative, ces changements font réagir les syndicats, qui développent de nouvelles stratégies d'action. Bien que cela ne leur restitue pas leur influence passée, elle en éloigne la crise prévue. Finalement, l'auteur soutient que les syndicats sont touchés de manières différentes, suivant les arrangements institutionnels qui leur sont propres. 